(c) 2017, THE AUTHORS. Published by FASS and Elsevier Inc. on behalf of the American Dairy Science Association ${ }^{\circledR}$.

This is an open access article under the CC BY-NC-ND license (http://creativecommons.org/licenses/by-nc-nd/3.0/).

\title{
Invited review: Large-scale indirect measurements for enteric methane emissions in dairy cattle: A review of proxies and their potential for use in management and breeding decisions
}

\author{
E. Negussie, ${ }^{* 1}$ Y. de Haas,† F. Dehareng,‡ R. J. Dewhurst,§ J. Dijkstra,\# N. Gengler,II D. P. Morgavi,ף \\ H. Soyeurt,II S. van Gastelen,\# T. Yan, ${ }^{* *}$ and F. Biscarini††ł‡ \\ *Biometrical Genetics, Green Technology, Natural Resources Institute Finland (Luke), FIN-31600 Jokioinen, Finland \\ †Animal Breeding and Genomics Centre of Wageningen Livestock Research, PO Box 338, NL-6700 AH Wageningen, the Netherlands \\ $\ddagger$ Valorisation of Agricultural Products, Walloon Agricultural Research Center (CRA-W), BEL-5030 Gembloux, Belgium \\ $\S$ Scotland's Rural College, King's Buildings, West Mains Road, Edinburgh EH9 3JG, United Kingdom \\ \#Animal Nutrition Group, Wageningen University and Research, PO Box 338, NL-6700 AH Wageningen, the Netherlands \\ $\|$ Agriculture, Bio-engineering and Chemistry, Gembloux Agro-Bio Tech, University of Liège, BEL-5030 Gembloux, Belgium \\ IUMR1213 Herbivores, INRA, Vetagro Sup, 63122, Saint-Genès-Champanelle, France \\ ${ }^{* *}$ Agri-Food and Biosciences Institute, Hillsborough, Co. Down BT26 6DR, United Kingdom \\ ††Department of Bioinformatics, PTP Science Park, Via Einstein Loc. Cascina Codazza, 26900 Lodi, Italy \\ ¥¥Faculty of Bioscience and Technology for Food, Agriculture and Environment, University of Teramo, via R. Balzarini 164100 Teramo, Italy
}

\begin{abstract}
Efforts to reduce the carbon footprint of milk production through selection and management of low-emitting cows require accurate and large-scale measurements of methane $\left(\mathrm{CH}_{4}\right)$ emissions from individual cows. Several techniques have been developed to measure $\mathrm{CH}_{4}$ in a research setting but most are not suitable for large-scale recording on farm. Several groups have explored proxies (i.e., indicators or indirect traits) for $\mathrm{CH}_{4}$; ideally these should be accurate, inexpensive, and amenable to being recorded individually on a large scale. This review (1) systematically describes the biological basis of current potential $\mathrm{CH}_{4}$ proxies for dairy cattle; (2) assesses the accuracy and predictive power of single proxies and determines the added value of combining proxies; (3) provides a critical evaluation of the relative merit of the main proxies in terms of their simplicity, cost, accuracy, invasiveness, and throughput; and (4) discusses their suitability as selection traits. The proxies range from simple and low-cost measurements such as body weight and high-throughput milk mid-infrared spectroscopy (MIR) to more challenging measures such as rumen morphology, rumen metabolites, or microbiome profiling. Proxies based on rumen samples are generally poor to moderately accurate predictors of $\mathrm{CH}_{4}$, and are costly and difficult to measure routinely onfarm. Proxies related to body weight or milk yield and composition, on the other hand, are relatively simple,
\end{abstract}

\footnotetext{
Received September 21, 2016.

Accepted December 7, 2016.

${ }^{1}$ Corresponding author: Enyew.negussie@luke.fi
}

inexpensive, and high throughput, and are easier to implement in practice. In particular, milk MIR, along with covariates such as lactation stage, are a promising option for prediction of $\mathrm{CH}_{4}$ emission in dairy cows. No single proxy was found to accurately predict $\mathrm{CH}_{4}$, and combinations of 2 or more proxies are likely to be a better solution. Combining proxies can increase the accuracy of predictions by 15 to $35 \%$, mainly because different proxies describe independent sources of variation in $\mathrm{CH}_{4}$ and one proxy can correct for shortcomings in the other(s). The most important applications of $\mathrm{CH}_{4}$ proxies are in dairy cattle management and breeding for lower environmental impact. When breeding for traits of lower environmental impact, single or multiple proxies can be used as indirect criteria for the breeding objective, but care should be taken to avoid unfavorable correlated responses. Finally, although combinations of proxies appear to provide the most accurate estimates of $\mathrm{CH}_{4}$, the greatest limitation today is the lack of robustness in their general applicability. Future efforts should therefore be directed toward developing combinations of proxies that are robust and applicable across diverse production systems and environments.

Key words: enteric methane, dairy cattle, proxy, breeding, management

\section{INTRODUCTION}

Increases in milk production through management and genetics have substantially improved feed efficiency and decreased costs per unit of product over recent decades. However, dairy systems are also associated with environmental costs (Baskaran et al., 2009), with 
the methane $\left(\mathrm{CH}_{4}\right)$ emissions associated with rumen microbial fermentation being both an important contributor to global greenhouse gas (GHG) emissions and an avoidable loss of energy that could otherwise be directed into milk production. The livestock sector is responsible for $14.5 \%$ of the global anthropogenic GHG emissions (Gerber et al., 2013). Dairy cattle account for $18.9 \%$ of these emissions, mainly in the form of enteric $\mathrm{CH}_{4}$ emissions (van Middelaar et al., 2014b).

Several $\mathrm{CH}_{4}$ phenotypes have been defined (Herd et al., 2013); the most widely used is $\mathrm{CH}_{4}$ production $(\mathbf{M e P})$ in liters or grams per day. The problem in selecting for this trait is that it is highly correlated with feed intake and, consequently, with the ultimate breeding goal in dairy cattle: milk production. Alternative phenotypes are $\mathrm{CH}_{4}$ intensity (MeI), which is defined as liters or grams of $\mathrm{CH}_{4}$ per kilogram of milk, and $\mathrm{CH}_{4}$ yield (MeY), which is defined as liters or grams of $\mathrm{CH}_{4}$ per kilogram of DMI. Residual $\mathrm{CH}_{4}$ production (RMP) is calculated as observed minus predicted $\mathrm{CH}_{4}$ production (Herd et al., 2014; Berry et al., 2015), with predicted values based on factors such as milk production, BW, and feed intake. At the moment, it is not obvious which of these phenotypes to use but it is important to monitor associations between the chosen $\mathrm{CH}_{4}$ phenotype and the other important traits in the breeding goal (e.g., production, fertility, longevity) to avoid unfavorable consequences.

Although diet changes and feed additives can be effective mitigation strategies for $\mathrm{CH}_{4}$ emissions (e.g., Beauchemin et al., 2009; Martin et al., 2010; Hristov et al., 2013b), their effects depend on continued use of the diet or additive and the rumen microbiome can adapt to additives. In contrast, breeding for reduced $\mathrm{CH}_{4}$ emissions would have a permanent and cumulative effect (Wall et al., 2010). Several studies have shown that $\mathrm{CH}_{4}$ emissions by ruminants have a genetic component, with heritability in the range of 0.20 to 0.30 (e.g., de Haas et al., 2011; Donoghue et al., 2013; Pinares-Patiño et al., 2013; Kandel et al., 2014; Lassen and Løvendahl, 2016). Breeding for reduced $\mathrm{CH}_{4}$ emissions, alone or together with other mitigation strategies, could therefore be effective in reducing the environmental impact of cattle farming and, possibly, also in increasing feed efficiency. Such breeding scheme would require, as a fundamental starting point, accurate measures of individual $\mathrm{CH}_{4}$ emissions on a large scale.

Several techniques have been developed for the measurement of $\mathrm{CH}_{4}$ emissions from ruminants, with varying degrees of accuracy (see review by Hammond et al., 2016), but routine individual measurements on a large scale (a requisite for genetic selection) have proven difficult to obtain and expensive (Pickering et al., 2015; Negussie et al., 2016). Therefore, identifying proxies (i.e., indicators or indirect traits) that are correlated with $\mathrm{CH}_{4}$ emission but that are easy and relatively low cost to record on a large scale is a much-needed alternative. Proxies might be less accurate but could be measured repeatedly to reduce random noise.

Previous studies have reported a large array of $\mathrm{CH}_{4}$ proxies; for example, milk MIR (Dehareng et al., 2012), rumen metagenome profiles (Ross et al., 2013b), and milk fatty acid profiles (Chilliard et al., 2009; Dijkstra et al., 2016), differing widely in accuracy and applicability under different conditions. The ideal proxy would be phenotypically and genetically highly correlated with $\mathrm{CH}_{4}$ emissions and cost effective, and it should be easily, and potentially repeatedly, measured on a large scale. A systematic summary and assessment of existing knowledge is needed for the identification of robust and accurate $\mathrm{CH}_{4}$ proxies for future use. To fill this gap, this review aims to (1) systematically describe the biological basis of current potential $\mathrm{CH}_{4}$ proxies for dairy cattle; (2) assess the accuracy and predictive power of single proxies and determine the added value of combining proxies; (3) provide a critical evaluation of the relative merit of the main proxies in terms of their simplicity, cost, invasiveness and throughput; and (4) discuss their suitability as selection traits.

\section{DESCRIPTION OF PROXIES FOR $\mathrm{CH}_{4}$ EMISSIONS}

This section presents a systematic review of available methane proxies, with measurement/sampling sites arranged according to the chronological progression of nutrients through the animal: (1) feed intake and feeding behavior; (2) rumen function, metabolites, and microbiome; (3) milk production and composition; (4) hindgut and feces; and (5) measurements at the level of the whole animal.

\section{Feed Intake}

Enteric $\mathrm{CH}_{4}$ is a by-product of microbial fermentation in the rumen (principally) and hindgut of animals. Feed intake is therefore one of the major drivers of MeP (Mills et al., 2003; Ellis et al., 2007; Moraes et al., 2014), along with the fermentability of feed (Hristov et al., 2013b). Scientific evidence has shown that DMI $(\mathrm{kg} / \mathrm{d})$ and metabolizable energy (ME) intake $(\mathrm{MJ} / \mathrm{d})$ appear to be reasonably adequate predictors of MeP. According to Ellis et al. (2007), DMI predicted MeP with an $\mathrm{R}^{2}$ of 0.64 , and ME intake $(\mathrm{MJ} / \mathrm{d}$ ) predicted $\mathrm{MeP}$ with an $\mathrm{R}^{2}$ of 0.53 for dairy cattle. This is in agreement with previous literature reports. For instance, Mills et al. (2003) showed that DMI predicted $\mathrm{MeP}$ with an $\mathrm{R}^{2}$ of 0.60 , and $\mathrm{ME}$ intake predicted $\mathrm{MeP}$ with an $\mathrm{R}^{2}$ of 0.55 . More recently, Moraes et al. (2014) 
identified gross energy intake $(\mathbf{G E})$ as a key explanatory variable for predicting $\mathrm{CH}_{4}$ emission; GE intake predicted $\mathrm{CH}_{4}$ emission with root mean squared prediction error $(\mathrm{MJ} / \mathrm{d})$ of 3.01. Residual feed intake (RFI), a feed efficiency trait, is also related to $\mathrm{CH}_{4}$ emission in ruminants. Studies have shown that selection of animals for low RFI (high feed efficiency) reduces methane emissions in cattle (Nkrumah et al., 2006; Hegarty et al., 2007; Fitzsimons et al., 2013; Negussie et al., 2014), suggesting a sustainable strategy to improve feed efficiency and simultaneously lower $\mathrm{CH}_{4}$ output. However, there are some inconsistencies in relation to differences in feed intake and corresponding methane emissions between low and high RFI animals (Jones et al., 2011; Fitzsimons et al., 2013), with MeY observed to be higher for low RFI heifers (McDonnell at al., 2016). Such conflicting observations on the variation in methane emission of high- and low-efficiency animals between studies may suggest that selection of cattle for increased feed efficiency may not necessarily result in a reduction in methane emissions (Freetly and BrownBrandl, 2013).

\section{Feeding Behavior}

Feeding behavior is related to $\mathrm{MeP}$ in ruminants, but the magnitude and direction of the relationship varies across studies. For instance, Nkrumah et al. (2006) found a negative relationship between daily feed bunk attendance and $\mathrm{MeP}$, whereas feeding duration was positively correlated with MeP. More recent work assessed the ability of short-term measurements of $\mathrm{CH}_{4}$ emissions to predict daily emissions of beef cattle fed alfalfa silage at different levels and frequencies of feeding (Jonker et al., 2014). Feeding frequencies affected circadian patterns of MeP but not MeY. Specifically, the range in hourly $\mathrm{CH}_{4}$ emission rates during the day decreased with increasing feed intake level but was unaffected by feeding frequency (Jonker et al., 2014).

\section{Rumination Time}

Rumination patterns and duration affect particle breakdown and colonization in the rumen and so have important effects on rumen fermentation (Harb and Campling, 1985; Schirmann et al., 2012), opening up the possibility of using rumen motility as proxy for $\mathrm{CH}_{4}$ emissions. The potential association between rumination time and $\mathrm{CH}_{4}$ emissions has been largely unexplored until recently. In a recent study, Watt et al. (2015) compared 2 groups of dairy cows ( $\mathrm{n}=37$ cows/ group) with divergent rumination times. Cows with high rumination activity produced more milk, consumed more concentrate, and produced more $\mathrm{CH}_{4}$ than low rumination contemporaries. Nevertheless, there was insufficient evidence from that study to support a direct or indirect association between rumination and MeP. In contrast, high rumination cows had higher milk production and had lower RMP and MeI than the low rumination group, confirming that increasing milk production efficiency is one strategy to lower the carbon footprint of milk production from dairy systems. However, selection solely to improve production efficiency runs the risk of increasing feed intake and $\mathrm{CH}_{4}$ emissions per animal and hence total emissions. To address this one plausible strategy could be to increase animal productive efficiency while reducing $\mathrm{CH}_{4}$ emissions per animal. This could be achieved by reducing MeY or decreasing DMI, or both, provided that there is no concomitant reduction in productivity or increase in feed consumption (Pickering et al., 2015).

\section{Rumen Function, Metabolites, and Microbiome}

The majority of methanogenesis takes place in the rumen, and a lesser proportion $(\sim 13 \%)$ of $\mathrm{CH}_{4}$ is produced in the cecum and colon (Murray et al., 1976; Muñoz et al., 2012). Because methanogens are the exclusive producers of $\mathrm{CH}_{4}$, it is logical to assume that their number and activity would be linked to $\mathrm{CH}_{4}$ emissions. In addition, in the complex trophic web of the gastrointestinal microbiota, microbes producing or competing for substrates used by methanogens will have a marked effect on MeP (Morgavi et al., 2010). Supplementary Table S1 (https://doi.org/10.3168/jds.2016-12030) provides an overview of published literature on the effects of antimethanogenic treatments and dietary manipulations designed to alter $\mathrm{MeP}$ or $\mathrm{MeY}$ on rumen VFA proportions and the rumen microbiota, particularly methanogens and protozoa numbers.

Methanogens as Proxies. There has been some variability in relationships between methane emissions and the abundance of rumen methanogens when antimethanogenic compounds have been fed. For instance, inhibitors of the enzyme methyl coenzyme-M reductase (which is involved in the last step of the methanogenic pathway), such as bromochoromethane (Denman et al., 2007), chloroform (Knight et al., 2011), or 3-nitrooxypropanol (Haisan et al., 2014), did not always result in a reduction of methanogen numbers (Romero-Perez et al., 2014, 2015). Other compounds known for their antimicrobial activities were also shown to induce reductions in both MeP and methanogen numbers (Kubo et al., 1993; Iwamoto et al., 2002). Examples of these are nitrates (van Zijderveld et al., 2010; Veneman et al., 2015), anacardic acid contained in cashew nut shell liquid (Shinkai et al., 2012), monensin (Shinkai et al., 2012), and isobutyrate (Wang et al., 2015). 
The relationship between rumen methanogen abundance and methanogenesis is less clear when changes in enteric $\mathrm{CH}_{4}$ emissions are modulated by diet or are a consequence of selecting phenotypes related to feed efficiency or MeY. Whereas in some reports, significant positive relationships were identified (Aguinaga Casañas et al., 2015; Arndt et al., 2015; Sun et al., 2015; Wallace et al., 2015), in many others, the concentration of methanogens was unrelated to methanogenesis (e.g., Morgavi et al., 2012; Kittelmann et al., 2014; Shi et al., 2014; Bouchard et al., 2015). Bouchard et al. (2015) even reported a reduction in methanogens without a significant decrease in $\mathrm{MeP}$ for steers fed sainfoin silage. Sheep selected for high or low MeY showed no differences in methanogen abundance, although there was a strong correlation with expression of archaeal genes involved in methanogenesis (Shi et al., 2014). This difference in archaeal gene expression (i.e., the $m c r A$ gene) as opposed to methanogen abundance has been reported by others (Popova et al., 2011). However, in other studies, no relationship was found between archaeal gene expression and MeY (Aguinaga Casañas et al., 2015). Some methodological and experimental differences might explain some of these apparent contradictions, such as the type of gene target and primers used for nucleic acid amplification. Effects are seen most clearly when the difference in MeP between groups of animals is large; for example, Wallace et al. (2015) used treatments that generated a 1.9-fold difference in $\mathrm{CH}_{4}$ emissions. Roehe et al. (2016) observed that the ranking of sire groups for $\mathrm{CH}_{4}$ emissions measured with respiration chambers was the same as that for ranking on archaea:bacteria ratio, providing further evidence that host control of archaeal abundance contributes to genetic variation in $\mathrm{CH}_{4}$ emissions, at least in some circumstances. Across a wide geographical range, the methanogenic archaea were shown to be highly conserved across the world (Henderson et al., 2015). This universality and limited diversity might make it possible to mitigate $\mathrm{CH}_{4}$ emissions by developing strategies that target dominant rumen methanogens.

Protozoa and Other Rumen Microbes as Proxies. Protozoa are net producers of $\mathrm{H}_{2}$ and their absence from the rumen is associated with an average reduction in enteric MeP of $~ 11 \%$ (Hegarty, 1999; Morgavi et al., 2010; Newbold et al., 2015). Using a database of 28 experiments and 91 dietary treatments, Guyader et al. (2014) showed a significant decrease of $8.14 \mathrm{~g}$ of $\mathrm{CH}_{4} /$ $\mathrm{kg}$ of DMI for each log-unit reduction in rumen protozoal abundance. About $21 \%$ of experiments within this data set reported $\mathrm{CH}_{4}$ changes unrelated to protozoal abundance, highlighting the multifactorial nature of methanogenesis.
Simultaneous monitoring of microbial populations together with $\mathrm{CH}_{4}$ emissions brings interesting insights into the complex microbial interactions influencing rumen methanogenesis. Low- $\mathrm{CH}_{4}$-emitting microbial communities were associated with higher relative proportions of Fibrobacteres, Quinella ovalis, and other Veillonellaceae such as Selenomononas, in contrast to lower proportions of Ruminococcaceae, Lachnospiraceae, and other Clostridiales (Kittelmann et al., 2014; Wallace et al., 2014; Sun et al., 2015). Fibrobacteres, Quinella, and Selenomononas are broadly known to consume $\mathrm{H}_{2}$ whereas Ruminococcaceae, Lachnospiraceae, and other Clostridiales produce $\mathrm{H}_{2}$ during fermentation, and changes in the proportion of these populations would reduce the amount of $\mathrm{H}_{2}$ available for methanogenesis. In the rumen, these microbial changes are biochemically associated with higher proportions of propionate (Kittelmann et al., 2014; Wallace et al., 2014; Sun et al., 2015).

Rumen Microbiome Profile and Microbial Genes as Proxies. Ross et al. (2013b) developed a metagenomic approach for the prediction of $\mathrm{MeP}$ in cattle. Metagenomic profiles, based on untargeted massively parallel sequencing, provide relative abundances for several thousand microbial species. This group generated a data set of Bos taurus rumen metagenome samples (Ross et al., 2013a) with associated MeP taken from 3 experiments. They predicted MeP using each of the 3 bovine data sets as the reference population, and predicted the phenotypes of animals in the other 2 data sets. Using this approach, Ross et al. (2013a) predicted $\mathrm{MeP}$ with $\mathrm{R}^{2}$ of up to 0.55 . One clear limitation of metagenomic predictions compared with genomic predictions is that the microbiome of the host is variable; that is, it may change in response to diet or other environmental factors over time, whereas the host's DNA remains constant. Roehe et al. (2016) also conducted rumen metagenomic analysis from 8 beef cattle divergent for $\mathrm{CH}_{4}$ emissions and demonstrated that 20 microbial genes (out of 3,970 identified) were significantly related to $\mathrm{CH}_{4}$ emissions. These included genes involved in the first and last steps of methanogenesis: formylmethanofuran dehydrogenase subunit B $(f m d B)$ and methyl-coenzyme $M$ reductase $\alpha$ subunit ( $m c r A)$, which were 170 times more abundant in high-emitting cattle. Although gene-centric metagenomics is not low cost or high throughput, these results point to potential future proxy approaches using inexpensive gene chips.

\section{Rumen Volume and Retention Time}

Another potentially useful diagnostic feature of the rumen is its volume. Several studies have shown that 
the size of the rumen and its retention time are related to $\mathrm{CH}_{4}$ emission (Pinares Patiño et al., 2003; Barnett et al., 2012; Goopy et al., 2014). Rumen volume was determined by X-ray computed tomography scanning in the study by Goopy et al. (2014), which demonstrated that low-MeY sheep had smaller rumens. The rumen content morphology score also tended to differ between the groups, suggesting that there may be a structural difference in the relationship among the solid, liquid, and air phases of the rumen contents between highand low- $\mathrm{CH}_{4}$-emitting sheep. Faster passage of material from the rumen results in a reduction in the time available to ferment substrate (Goopy et al., 2014). The differences recorded by Goopy et al. (2014) may be related to feeding the sheep at a fixed energy requirement level, and those authors proposed that the work should be repeated with animals fed ad libitum. Apparent totaltract digestibility did not differ between high- and low-MeY groups in that study, suggesting potential for postruminal digestion to compensate for reductions in rumen fermentation. This is in line with Barnett et al. (2012), who also demonstrated that a reduction, induced by injections of triiodothyronine, in whole-tract mean retention time reduced $\mathrm{MeY}$, and identified the possibility that blood triiodothyronine concentration may be a factor by which animal genotype affects mean retention time and thus a possible indicator of $\mathrm{MeY}$. Several other studies have used treatments to increase fractional passage rates from the rumen, with corresponding reductions in MeP. Rumen fractional passage rates explained $28 \%$ of variation in $\mathrm{MeP}$ in the study of Okine et al. (1989). Also, it seems likely that the reduction in $\mathrm{MeY}$ with increasing DMI observed in the study by Hammond et al. (2013) relates to increased rumen passage rates. In general, both characteristics including rumen volume, fill, and mean retention time appear to be strongly implicated in differential $\mathrm{MeY}$ and hence could be used as proxies for $\mathrm{CH}_{4}$ emission. However, Hammond et al. (2013) cautioned that in view of the fixed feeding level used, it is necessary to first determine whether these ruminal differences hold true for ad libitum diets as well as for dairy cattle. In addition, measurement of rumen volume via computed tomography scanning can be expensive and logistically challenging; so far, practical examples in large ruminants are not available.

\section{Rumen pH and VFA}

Supplementary Table S1 (https://doi.org/10.3168/ jds.2016-12030) provides a summary of recent studies that have estimated effects of a range of dietary treatments on $\mathrm{CH}_{4}$ emissions and measured metabolites (particularly VFA) and microorganisms in rumen fluid.
The stoichiometric relationships between VFA production and production of $\mathrm{H}_{2}$ (substrate for hydrogenotrophic methanogens) means that it is generally assumed that $\mathrm{CH}_{4}$ emissions are positively associated with the acetate:propionate ratio in ruminal fluid (e.g., Mohammed et al., 2011; Fievez et al., 2012). Although this relationship holds in some studies (e.g., Chung et al., 2011; Van Zijderveld et al., 2010), treatment effects on $\mathrm{CH}_{4}$ emissions and VFA proportions did not correspond in about half of the studies (e.g., Beauchemin et al., 2009; Brask et al., 2015; Supplementary Table S1; https://doi.org/10.3168/jds.2016-12030). Overall, the relations between $\mathrm{CH}_{4}$ emission and both VFA and $\mathrm{pH}$ are variable in the literature and not as straightforward as expected from theory. Across these studies, no consistent relationship has been identified between effects on $\mathrm{CH}_{4}$ emissions and effects on the microbiome.

\section{Milk Production and Composition}

Kirchgessner et al. (1995) used a modeling approach to estimate that, starting from an annual production rate of $110 \mathrm{~kg}$ from a dairy cow producing $5,000 \mathrm{~kg}$ of milk/yr, doubling milk production adds only $5 \mathrm{~kg}$ to $\mathrm{MeP}$ and so greatly reduces MeY. This effect was further described by Hristov et al. (2014). However, milk yield alone does not provide a good prediction of $\mathrm{MeP}$ in dairy cows. Yan et al. (2010) indicated that $\mathrm{CH}_{4}$ as a proportion of GE intake or milk energy output was negatively related to milk production. It is less clear if MeY can be predicted from milk yield when making comparisons across studies.

Milk solids yields or concentrations are another potential source for predicting $\mathrm{CH}_{4}$ emissions. Moraes et al. (2014) identified milk fat content as a key explanatory variable for predicting $\mathrm{CH}_{4}$ emissions of North American dairy and beef cattle. Kandel et al. (2014), however, found a low negative genetic correlation between infrared-predicted MeI (calibrated from $\mathrm{SF}_{6}$ tracer data) and fat yield $(\mathrm{g} / \mathrm{d} ; \mathrm{r}=-0.13)$. Using essentially the same $\mathrm{SF}_{6}$ tracer data, Vanlierde et al. (2015) found low phenotypic correlations between fat yield $(\mathrm{g} / \mathrm{d})$ and $\mathrm{SF}_{6} \mathrm{MeP}$ or $\mathrm{MeI}$ of 0.08 and -0.13 , respectively. Additionally, Kandel et al. (2014) found a moderate genetic correlation between infrared-predicted $\mathrm{MeI}$ (calibrated from $\mathrm{SF}_{6}$ tracer data) and protein yield $(\mathrm{g} / \mathrm{d} ; \mathrm{r}=-0.47)$. Based on same $\mathrm{SF}_{6}$ tracer data, Vanlierde et al. (2015) found low to moderate phenotypic correlations between protein yield $(\mathrm{g} / \mathrm{d})$ and $\mathrm{SF}_{6} \mathrm{MeP}$ or MeI of 0.53 and -0.09 , respectively. Further, Dehareng et al. (2012) observed a low correlation between milk lactose content and $\mathrm{MeI}(\mathrm{r}=0.19)$ and, based on the data used by Vanlierde et al. (2015), the correlation between milk lactose content and $\mathrm{MeP}$ or MeI was 0.33 
and -0.21 , respectively. Interestingly, Van Lingen et al. (2014) developed prediction equations for $\mathrm{MeY}$ and MeI, and total milk fat and milk protein content were never selected in any of the prediction models. Overall, these results suggests that major milk components have low potential as a proxy for $\mathrm{CH}_{4}$.

\section{Milk Fatty Acids}

Milk fatty acids (FA) are a particularly promising methane proxy because of the direct link to microbial digestion in the rumen. The fermentation of dietary carbohydrates in the rumen leads to the production of $\mathrm{H}_{2}$, and methanogenesis is the essential pathway to expel this $\mathrm{H}_{2}$ (Moss et al., 2000). The synthesis of acetate and $\beta$-hydroxybutyrate produces $\mathrm{H}_{2}$ that is then converted to $\mathrm{CH}_{4}$, while propionate synthesis consumes $\mathrm{H}_{2}$ (Demeyer and van Nevel, 1975). The de novo synthesis of milk FA in the mammary gland uses mostly acetate $(85 \%$ of de novo synthesized FA) but also $\beta$-hydroxybutyrate (10 to $15 \%$ ), and a limited amount of propionate to make short-chain FA (C4, C6, and C8), nearly all mediumchain FA (C10, C12, and C14), and approximately $60 \%$ of C16 (Chilliard et al., 2000; Couvreur et al., 2007). A positive relationship between VFA proportions and hydrogenotrophic methanogenesis is expected as a consequence of the common biochemical pathways between de novo synthesized milk FA and $\mathrm{CH}_{4}$ production. Furthermore, odd- and branched-chain FA might be related to $\mathrm{CH}_{4}$ emission because of their microbial origin, differences in the composition of major fibrolytic and amylolytic bacteria (Vlaeminck et al., 2006), and de novo synthesis of C15:0 and C17:0 with propionate as substrate (Fievez et al., 2012). Unsaturated fatty acids in milk originate from dietary unsaturated fatty acids, as well as from desaturation of saturated fatty acids in the mammary gland, and are negatively associated with enteric $\mathrm{CH}_{4}$ emissions (Grainger and Beauchemin, 2011). Because several long-chain unsaturated FA originate from dietary unsaturated FA, a negative relation can be expected between these long-chain unsaturated FA in the milk and $\mathrm{CH}_{4}$ emissions (Van Lingen et al., 2014).

Prediction equations have been developed to describe relationships between milk FA (measured using gas chromatography) and enteric $\mathrm{CH}_{4}$ emissions. Currently, data are available from 9 studies: Chilliard et al. (2009), Delfosse et al. (2010), Castro-Montoya et al. (2011), Dijkstra et al. (2011), Mohammed et al. (2011), Van Lingen et al. (2014), Williams et al. (2014), Dijkstra et al. (2016), and Rico et al. (2016). Most of these studies have been extensively reviewed by Van Gastelen and Dijkstra (2016). The prediction equations had $\mathrm{R}^{2}$ that ranged between 47 and $95 \%$, and the relation- ships between the individual milk FA and MeP differed considerably (Van Gastelen and Dijkstra, 2016). The differences between the studies might be the result of the different $\mathrm{CH}_{4}$ measurement techniques (e.g., cattle respiration chambers, $\mathrm{SF}_{6}$ tracer technique) and the way in which enteric $\mathrm{CH}_{4}$ is expressed (i.e., strong correlations between milk FA and $\mathrm{MeY}$ can disappear for MeI; Van Lingen et al., 2014; Dijkstra et al., 2016). More recently, Vanrobays et al. (2016) obtained results that suggest the correlations between enteric $\mathrm{CH}_{4}$ and milk FA vary throughout lactation, providing a further explanation for some of the diversity of results in literature.

\section{Milk Mid-Infrared Analysis}

Milk MIR spectroscopy is a relatively inexpensive, rapid, and routinely used technique in milk recording systems to predict fat, protein, lactose, and urea contents in milk to assist farm management decisions and breeding. It can be used as a promising strategy to exploit the link between enteric $\mathrm{CH}_{4}$ emission from ruminants and microbial digestion in the rumen by assessing the signature of digestion in milk composition. Milk MIR data can be obtained through regular milk recording schemes, as well as, on a herd level, through analysis used for milk payment systems. Diverse milk phenotypes can be obtained by MIR spectrometry, including detailed milk composition (e.g., FA as reported by Soyeurt et al., 2011), technological properties of milk, and cow physiological status (De Marchi et al., 2014; Gengler et al., 2016). Several of these novel traits (i.e., FA composition) have been identified as potential indicators of enteric $\mathrm{CH}_{4}$ emission. Therefore, using MIR to predict MeP (Dehareng et al., 2012; Vanlierde et al., 2013, 2015; Van Gastelen and Dijkstra, 2016) is a logical extension of its use to quantify major (i.e., fat, protein, casein, lactose, and urea) and minor milk components (e.g., FA). Dehareng et al. (2012) assessed the feasibility to predict individual $\mathrm{MeP}$ from dairy cows using milk MIR spectra. Their initial results suggest that this approach could be useful to predict $\mathrm{MeP}$ at the farm or regional scale, as well as to identify low$\mathrm{CH}_{4}$-emitting cows. According to Van Gastelen and Dijkstra (2016), MIR spectroscopy has the disadvantage that it has moderate predictive power for $\mathrm{CH}_{4}$ emission, both direct and indirect (i.e., via milk FA), and that it lacks the ability to predict important milk FA for $\mathrm{CH}_{4}$ prediction. They concluded that it may not be sufficient to predict MeP based on MIR alone. It is, however, possible to improve the accuracy of prediction through a combination of MIR with some animal characteristics such as lactation stage (Vanlierde et al., 2015). The advantage of this latter development is that 
this type of prediction can be done on a very large scale inside a routine milk recording system (Vanlierde et al., 2015).

\section{Hindgut and Feces}

Recent studies have explored the possibility of using fecal analysis to predict MeP (Froidmont et al., 2010; McCartney et al., 2013a,b). The membrane lipids of methanogens and other archaea contain distinctive ether lipids, such as the diether archaeol and tetraether caldarchaeol. Studies in other ecosystems have used these lipids as proxies for archaea (Wuchter et al., 2004), as well as the environment in which archaea are (or in the case of archeological samples: were) present. These compounds resist digestion and are found at elevated concentrations in feces (McCartney et al., 2014a).

Gill et al. (2010) evaluated feces from a range of herbivore species and showed that archaeol is distinctive to herbivores with foregut fermentation (rumen), whereas archaeol was undetectable in feces from hindgut fermenters. A significant relationship was found between fecal archaeol concentration and $\mathrm{MeP}$ across a range of diets when comparing treatment means (McCartney et al., 2013a). However, only a weak relationship was detected between individual estimates of $\mathrm{MeP}$ and fecal archaeol (McCartney et al., 2013b; Schwarm et al., 2015). There was no relationship between archaeol concentrations in rumen digesta and feces, most likely as a result of variation in the outflow of methanogens from the rumen (McCartney et al., 2014b). As a consequence, the fecal archaeol approach is unlikely to be useful to assess MeP from individual animals.

\section{Whole-Tract Digestibility}

Nutrient fermentation and absorption from the rumen is a major component of whole-tract digestibility; therefore, whole-tract digestibility may serve as a proxy for enteric $\mathrm{CH}_{4}$ emissions. An early work by Blaxter and Clapperton (1965) found a positive relationship $(P<0.001$, residual standard deviation: \pm 0.71$)$ between $\mathrm{CH}_{4}$ (\% of GE intake) and energy digestibility with sheep fed hay- or grass silage-based diets at the maintenance level. However, this relationship was not confirmed in several recent studies (Yan et al., 2009c; Ramin and Huhtanen, 2013; Stergiadis et al., 2016). Nonetheless, adding digestibility as a predictor variable to DMI or GE improved prediction accuracy. A similar result was obtained in a meta-analysis of calorimeter chamber data for beef cattle offered mixed diets (Yan et al., 2009c); energy digestibility along with GE intake improved the accuracy of $\mathrm{CH}_{4}$ prediction, despite the fact that there was no direct linear relationship between energy digestibility and MeY or percent of GE intake. In a meta-analysis of calorimeter data from dairy and beef cattle and sheep obtained from the scientific literature, Ramin and Huhtanen (2013) found that energy or $\mathrm{OM}$ digestibility had a positive effect on $\mathrm{MeP}$ when used as a secondary factor to support DMI or feeding level for prediction of MeP. These results confirm that whole-tract digestibility variables have potential as additional variables to improve the prediction of enteric $\mathrm{CH}_{4}$ emissions from cattle and sheep.

It is well documented that forage-based diets favor production of acetic and butyric acids in the rumen, whereas increasing dietary fiber concentration in general reduces energy and nutrient digestibility (Agricultural Research Council, 1980). Methane yield was positively related to the ratio of acetic and butyric acid divided by propionic acid (Moss et al., 2000). In a study specifically designed to evaluate the effects of grass maturity on digestibility and $\mathrm{MeP}$ in dry cows offered fresh grass-only diets at maintenance level, it was found that increasing ADF concentrations reduced whole-tract $\mathrm{OM}$ digestibility and also $\mathrm{CH}_{4}$ emissions (possibly because less fermentable $\mathrm{OM}$ was available during restricted feeding). However, the reduction rates for these 2 variables were different: increasing grass ADF concentrations from 25 to $35 \%$ reduced OM digestibility by $13.1 \%$, whereas $\mathrm{MeY}$ was only reduced by $5.6 \%$. Warner et al. (2016) reported that although increasing maturity of grass silage reduced both wholetract $\mathrm{OM}$ digestibility and $\mathrm{MeP}$ of lactating dairy cows, there was a poor relationship between the latter 2 variables, and OM digestibility could only explain a minor part of the variation in MeP. The conflicting effect of dietary fiber concentration on $\mathrm{MeP}$ and whole-tract digestibility would affect the value of digestibility as a proxy for enteric $\mathrm{CH}_{4}$ emissions. Indeed, recent calorimeter chamber studies did not detect any linear relationships between digestibility and $\mathrm{MeY}$ in grams per kilogram of DMI or percent of GE intake in cattle (Yan et al., 2009c; Stergiadis et al., 2016) and sheep (Zhao et al., 2016), despite the earlier findings of Blaxter and Clapperton (1965). Therefore, whole-tract digestibility variables cannot serve as primary predictors for enteric $\mathrm{MeP}$ in cattle or sheep, but might be used as additional variables to improve the accuracy of prediction of $\mathrm{CH}_{4}$ output.

\section{Whole Animal}

$B W$ and Conformation Traits. Body weight has been widely used as a primary predictor for enteric MeP from dairy and beef cattle (e.g., Holter and Young, 1992; Yan et al., 2009c; Moraes et al., 2014), especially where feed intake data are not available. Generally, 
heavier animals have higher maintenance requirements and thus eat more and produce more $\mathrm{CH}_{4}$. AntunesFernandes et al. (2016) found a relationship $(\mathrm{r}=0.44)$ between $\mathrm{BW}$ and $\mathrm{MeI}(\mathrm{g} / \mathrm{kg}$ of fat- and protein-corrected milk). A higher BW requires more feed to be used for maintenance purposes, thus less feed is available for milk production, which is expected to increase MeI. A relationship between $\mathrm{BW}$ and $\mathrm{MeY}$ was not found, however. There is a general relationship between BW and rumen capacity (Demment and Van Soest, 1985), such that when feed intake is kept constant, a higher rumen capacity results in a lower passage rate (Demment and Van Soest, 1985), resulting in a higher MeP (Moraes et al., 2014). From studies in sheep, BW seems to be a poor predictor of DMI and methane emissions (Moorby et al., 2015).

In cattle, BW can be predicted from 3-dimensional images (Kuzuhara et al., 2015) or from linear conformation traits (e.g., stature, chest width, body depth, angularity: Coffey et al., 2003; Yan et al., 2009a,b) although it is not routinely recorded in many countries. Because it is one of the explanatory variables for enteric MeP, it seems likely that linear conformation traits could be useful predictors as well. However, little information is currently available on the relationship between $\mathrm{MeP}$ and body conformation traits. Conformation traits may also be indicators for rumen volume, which affects enteric MeP through effects on feed intake and rumen passage rates. Body condition score is another conformation trait that may affect MeP. A fat animal may produce less $\mathrm{CH}_{4}$ than a lean animal at a given BW and offered the same diet, because body fat metabolism requires less energy than protein metabolism; thus, fat animals require less feed intake for maintenance (Agnew and Yan, 2000).

Animal Type and Lactation Stage. In a metaanalysis of calorimeter chamber data, which took into account differences in diet and feeding level, Yan et al. (2000) found no significant differences between dairy cows and beef cattle in terms of $\mathrm{CH}_{4}$ energy output as a proportion of GE or digestible energy intake. Similarly, there were no differences in these $\mathrm{CH}_{4}$ emission variables between Holstein and Norwegian dairy cows offered the same diets during early, mid, and late lactation (Yan, 2016). Lactation stage can provide a crude proxy for methane emissions from dairy cattle, based on a rough approximation of milk yield during lactation (Garnsworthy et al., 2012). Nonetheless, the value of lactation stage as a complementary proxy (discussed below) is illustrated by the improved accuracy realized due to inclusion of lactation stage alongside milk MIR spectral data in the analysis reported by Vanlierde et al. (2015).
Table 1 presents a summary of proxies reviewed in terms of their attributes, including simplicity, cost, accuracy, invasiveness, and throughput. Evaluation of proxies in these terms was based on the literature and discussions among experts of the METHAGENE project (Methagene, 2013). A closer look at this summary indicates that no single proxy offers a good solution in terms of all of these attributes, although the low cost and high throughput of milk MIR make it a good candidate for further work on refining methods, improving calibrations, and exploring best combinations with other proxies (as discussed below).

\section{COMBINING PROXIES FOR METHANE}

Although milk MIR shows promise as a single proxy for $\mathrm{CH}_{4}$ emissions, there may be advantages in using two or more proxies in combination. A combination of proxies might be appropriate for two reasons: (1) proxies may describe independent sources of variation in $\mathrm{CH}_{4}$ emissions, and (2) one proxy allows correction for shortcomings in the way the other proxy describes $\mathrm{CH}_{4}$ emissions (e.g., taking into account lactation stage if $\mathrm{CH}_{4}$ emission prediction coefficients change during the lactation).

\section{Combining Rumen Measurements as Proxies for Methane}

Rumen microbiome estimates have shown weak and variable relationships with $\mathrm{CH}_{4}$ emissions, both because the molecular techniques used are only semiquantitative and because of real biological effects. It will be useful to adopt more complex multivariate models to explore the relationship between the microbiome and $\mathrm{CH}_{4}$ emissions to accommodate the complexity and interactions among different microbial populations. Parallel consideration of other proxies (e.g., rumen VFA) might help in unravelling some of this complexity. Poulsen et al. (2013) suggested that methylotrophic methanogens (order Methanomassiliicoccales) may be important contributors to variation in $\mathrm{CH}_{4}$ emissions. This observation might explain some of the inconsistencies in relationships between ruminal acetate:propionate ratio and $\mathrm{CH}_{4}$ emissions, because the former is theoretically related only to hydrogenotrophic methanogenesis. A combination of rumen VFA and microbiome estimates might be more informative, even though, as far as we are aware, there are not yet sufficient studies with detailed microbiome profiles and rumen metabolite measurements to evaluate this proposition. Additionally, the absorption of the different VFA from the rumen is differentially affected by rumen $\mathrm{pH}$ so that rumen VFA 
proportions measured in rumen fluid do not necessarily provide a good basis for estimating VFA proportions actually produced in the rumen (Brask et al., 2015). It may be that a combination of rumen VFA proportions and $\mathrm{pH}$, perhaps with some modeling, might be more informative.

McCartney et al. (2013a) showed large variation in estimates of methanogen abundance in rumen fluid when using different primer sets to detect the same microbial target as determined by quantitative PCR. They also showed the potential value of adding a second proxy, a chemical marker for methanogens (archaeol), to help identify problems with the first (molecular biology) marker. Another example of potential benefits of combining methane proxies is fecal ether lipids. McCartney et al. (2014a) presented preliminary evidence that the ratio of diether to tetraether lipids (archaeol:GDGT0 ratio) varies in response to the $\mathrm{pH}$ challenge to rumen methanogens. It may be that adding a measurement or proxy for rumen $\mathrm{pH}$ would improve the relationship between fecal ether lipids and $\mathrm{CH}_{4}$ emissions. In addition, $\mathrm{pH}$ has a direct effect on rumen methanogens (Ann et al., 1996). Taking all this information together, combining measurements of rumen VFA, $\mathrm{pH}$, and the microbiome should be more informative for predicting $\mathrm{CH}_{4}$ emissions than any single measure.

\section{Modeling: Combining Proxies in Prediction Equations for Methane}

Factors affecting feed intake and consequently $\mathrm{CH}_{4}$ emissions should be included in models for estimating $\mathrm{CH}_{4}$ output. This is because feed intake is the main driver for $\mathrm{CH}_{4}$ emissions of ruminants (Moraes et al., 2014). Feed intake is mainly determined by BW, level of production (i.e., milk yield and composition), growth rate, and feed quality (e.g., forage proportion, protein and fiber contents). A range of other animal, management, and environment factors can influence feed intake, including BCS, lactation stage, pregnancy stage, age, parity, breed, grazing, housing, and weather conditions (e.g., temperature, wind, rain). Most of these factors influence feed intake and, consequently, also methane emissions, and should be included in models for predicting $\mathrm{CH}_{4}$. Feed intake also affects the types of VFA produced, but only after accounting for diet composition, retention time, and feeding behavior it is possible to draw the link between feed intake and VFA production (Ørskov and Ryle, 1990).

Combining Diet-Based Measurements with Other Proxies for Methane Emissions. As shown above, feed intake appears to be a reasonable predictor of MeP. However, a substantial level of variation is left unaccounted for, suggesting that information on dietary composition is needed. This is also important when considering diets of similar DMI but of different nutrient profiles. Ellis et al. (2010) demonstrated that the more generalized $\mathrm{MeP}$ prediction equations performed worse than those that attempted to take important aspects of diet composition into account. The prediction accuracy of $\mathrm{MeP}$ depends on the accuracy of quantifying the VFA produced in the rumen (Alemu et al., 2011), and the type of VFA formed during rumen fermentation depends on the type of substrate fermented (e.g., starch and NDF; Bannink et al., 2011). This indicates that including a description of variation in dietary quality caused by nutritional factors might result in improved prediction accuracy of $\mathrm{CH}_{4}$ emission (Ellis et al., 2010; Moraes et al., 2014).

Ramin and Huhtanen (2013) showed a range of prediction equations for $\mathrm{CH}_{4}$ production in dairy cows that were developed from respiration chamber data. Feed intake was the primary predictor of total $\mathrm{CH}_{4}$ production. Variation in feed intake alone accounted for 52 to $64 \%$ of daily $\mathrm{CH}_{4}$ production when cattle were fed ad libitum (Knapp et al., 2014). In addition, $\mathrm{CH}_{4}$ production was positively related to diet digestibility and negatively related to dietary fat content, whereas dietary carbohydrate composition had only minor effects. Combining more factors did indeed improve the prediction equation by 15 to $35 \%$, but all factors were still related to feed intake and diet composition, which may lead to multicollinearity. Multicollinearity arises when 2 or more predictor variables are strongly correlated, leading to some coefficient estimates getting inflated in one direction and the others for correlated variables in the opposite direction. Severe (multi)collinearity can be a problem because it can (1) obscure the interpretability of results; (2) increase the variance of estimates thus making them very sensitive to minor changes in the model; (3) reduce the statistical power of the analysis; and (4) lead to problems with linear dependencies when solving the model. As a result, estimates of the quantities of interest may become difficult to obtain, unstable, and hard to interpret. Therefore, care should be taken when choosing which variables (proxies) to include and how to combine them in a predictive model for $\mathrm{CH}_{4}$ in dairy cows.

Combining Milk-Based Measurements with Other Proxies for Methane Emissions. As reviewed by Van Gastelen and Dijkstra (2016), milk FA have potential to predict $\mathrm{CH}_{4}$ emission, but their predictive power may be improved by including other proxies. Mohammed et al. (2011) used rumen measurements (i.e., VFA, pH, and protozoa counts), feed intake (i.e., total DMI, forage DMI, and FA intake), and production parameters (i.e., milk yield and composition) in combination with milk FA. The results suggest that 
NEGUSSIE ET AL.

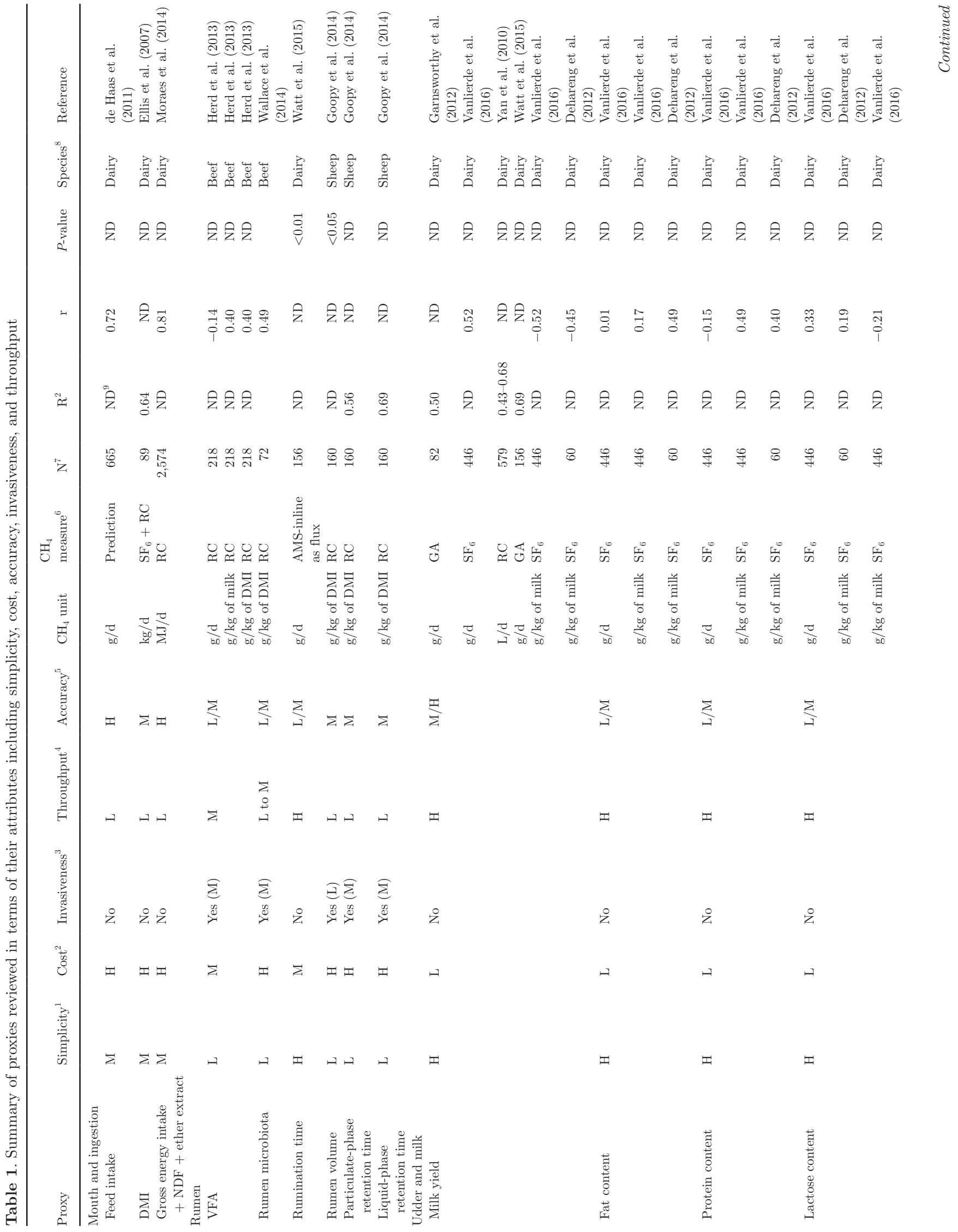


INVITED REVIEW: PROXIES FOR METHANE IN MANAGEMENT AND BREEDING DECISIONS

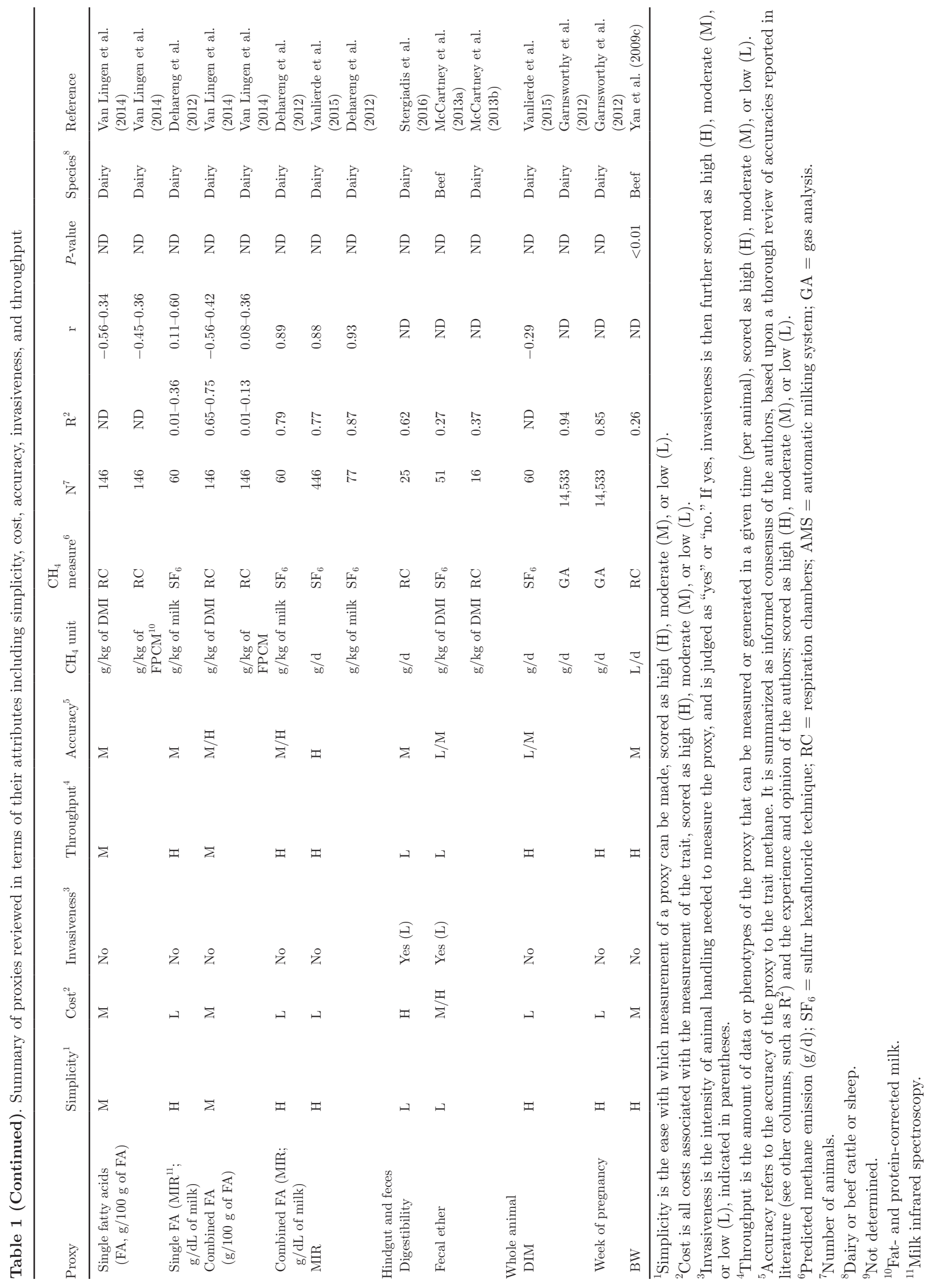


milk FA predict $\mathrm{CH}_{4}$ emission better $\left(\mathrm{R}^{2}=0.74\right)$ compared with rumen variables, feed intake, and production parameters $\left(\mathrm{R}^{2}<0.58\right)$. However, combining milk FA with feed intake and production parameters resulted in a model $\mathrm{R}^{2}$ of 0.83 , and combining milk FA with feed intake, production, and rumen-related parameters resulted in a model $R^{2}$ of 0.90 . These observations confirm expectations that combination of proxies can result in a more accurate estimation of $\mathrm{CH}_{4}$ emission.

Mohammed et al. (2011) also compared $\mathrm{CH}_{4}$ emission with $\mathrm{CH}_{4}$ emission predicted by the equations of Chilliard et al. (2009) and Dijkstra et al. (2011), observing over-prediction of $\mathrm{CH}_{4}$ emission. This indicates that the relation between milk FA and $\mathrm{CH}_{4}$ emission may be diet specific, which is in agreement with Dijkstra et al. (2016). Dijkstra et al. (2016) compared observed $\mathrm{CH}_{4}$ emission of dairy cattle fed grass- and grass silage-based diets with $\mathrm{CH}_{4}$ emission predicted with the equation developed by Van Lingen et al. (2014). The Van Lingen et al. (2014) equations do not seem to accurately predict MeY and MeI. This indicates that the relation between milk FA profile and $\mathrm{CH}_{4}$ emission in dairy cows fed grass- and grass silage-based diets differs from that with other types of diets, and suggests that diet-specific prediction equations may need to be developed or diet composition may need to be included in the prediction equations.

Rico et al. (2016) combined feed intake, diet composition (i.e., CP content, NDF content, starch content, and fat content), and milk production with milk FA to develop $\mathrm{CH}_{4}$ prediction equations. The best fit was observed for the model combining milk FA, feed intake, diet composition, and milk production $\left(\mathrm{R}^{2}=0.84\right)$, which was slightly better than the model combining only milk FA and diet composition $\left(\mathrm{R}^{2}=0.80\right)$. This indicates that feed intake and milk yield are valuable proxies in combination with milk FA and diet composition.

Although Dehareng et al. (2012) showed that it is feasible to predict dairy cow $\mathrm{CH}_{4}$ emissions using MIR spectroscopy (the cross-validated $\mathrm{R}^{2}$ ranged between 0.68 and 0.79 ), predictions at different stages of lactation were not biologically meaningful. Although lactation stage was a poor $\mathrm{CH}_{4}$ predictor when considered alone, Vanlierde et al. (2015) showed that its combination with MIR refined the model. They developed lactation stage-independent (i.e., including only MIR; equivalent to Dehareng et al., 2012) and lactation stagedependent (i.e., including MIR plus DIM to describe lactation stage) $\mathrm{CH}_{4}$ prediction equations. The average $\mathrm{CH}_{4}$ production $(\mathrm{g} / \mathrm{d})$ predicted by both models was similar $(416 \pm 63 \mathrm{~g} / \mathrm{d})$. However, in contrast to the lactation stage-independent prediction equation, the lactation stage-dependent prediction equation showed biologically meaningful behavior throughout lactation: an increase in $\mathrm{CH}_{4}$ production (g/d) after calving up to approximately 100 DIM, followed by a gradual decline toward the end of lactation (Vanlierde et al., 2015). These results indicate the importance of combining milk MIR with lactation stage to improve the prediction of $\mathrm{CH}_{4}$ emission in dairy cows. This result could be important for further development of milk FA-based $\mathrm{CH}_{4}$ prediction equations (Vanrobays et al., 2016).

\section{PROXIES: APPLICATIONS TO CATTLE MANAGEMENT AND BREEDING}

Methane emissions are not (yet) directly relevant in daily herd management and neither are they included in breeding goals for dairy cattle. There is currently no incentive to include enteric $\mathrm{MeP}$ in the breeding goal, even though there is great interest in reducing the release of GHG, which represents a loss of dietary energy in ruminants and is an important contributor to global warming. The incentive could be monetary if financial rewards or penalties were introduced, but could also be environmental or social. A financial reward/penalty for low-/high-emission milk might serve as a good incentive, because it would encourage dairy producers to lower the carbon footprint of milk production. Similarly, if consumers demand more environment friendly livestock products and are willing to pay for this, dairy producers would be interested in putting in extra effort to ensure that their herds have low environmental impact. One problem in this regard would be the difficulty of accounting for nonmarket values of environmental and social factors. To address this, Nielsen and Amer (2007) have shown that nonmarket values for traits under selection could be estimated by considering the consumer's "willingness to pay" for aspects that have perceived societal or animal welfare value. Alternatively, Martin-Collado et al. (2015) have used "1000 minds" methodology to add objectivity to perceived nonmarket values through a survey, where questions on perceived values are assessed through a series of comparisons that are of similar actual value.

\section{Applications of Proxies to Cattle Management}

Obviously, reduction of $\mathrm{CH}_{4}$ emissions could be achieved by simply reducing livestock numbers. However, the global demand for animal products is growing, with meat and milk consumption projected to double by 2050 (Gerber and Steinfeld, 2008). Therefore, it is critical to produce more food (e.g., milk) while minimizing environmental impact.

For sustainable milk production, $\mathrm{CH}_{4}$ mitigation strategies and the estimated environmental impact per 
unit product from a dairy system are required (Capper et al., 2009). In terms of management mitigation strategies, the single most effective GHG mitigation strategy is to increase animal productivity (Hristov et al., 2013a). An increase in animal productivity, which can be achieved through improvements in animal genetics, feeding, reproduction, health, and overall management of the animal operation, may allow a reduction of the number of animals needed to maintain constant output with a reduced environmental footprint (Hristov et al., 2013a). Additionally, several potentially effective dietary $\mathrm{CH}_{4}$ mitigation practices are available for livestock (reviewed by Hristov et al., 2013b).

Robust and accurate estimates of $\mathrm{CH}_{4}$ emission on a large scale are needed to evaluate effects of mitigation strategies, and proxies can be used to achieve this objective. This becomes evident when comparing the prediction accuracy of the Intergovernmental Panel on Climate Change (IPCC) Tier 2 model (IPCC, 2006), which works with a fixed $\mathrm{CH}_{4}$ conversion rate factor (i.e., $6.5 \%$ of $\mathrm{GE}$ intake) to estimate $\mathrm{CH}_{4}$ emission of dairy cows, with the IPCC Tier 3 model (Bannink et al., 2011), which combines feed intake with diet composition. The IPCC Tier 2 model cannot differentiate between a change in $\mathrm{CH}_{4}$ emission caused by an increase in DMI or a change in $\mathrm{CH}_{4}$ emission caused by an increased dietary fat content, which would have different effects on the resulting $\mathrm{CH}_{4}$ emission but may not differ in GE intake (Gerber et al., 2013). Thus, proxies - in this example, diet composition - can evaluate impacts of mitigation strategies better.

Many studies have shown the $\mathrm{CH}_{4}$ reduction potential of specific dietary strategies at the animal level (e.g., Grainger and Beauchemin, 2011), but a life cycle assessment is needed to determine whether the mitigation strategy would result in a net reduction of $\mathrm{CH}_{4}$ emission over the whole chain (Van Middelaar et al., 2013, 2014a). For example, at the animal level, replacing grass or grass silage with corn silage in the diet is a valuable strategy with an immediate effect in reducing GHG emissions (e.g., Beauchemin et al., 2008; Van Gastelen et al., 2015). However, at the farm and chain level, the strategy is not applicable for farms that cannot further reduce their grassland surface because of compliance with the European Union (EU) derogation regulation. This derogation regulation is specific for several EU countries and allows farmers to apply up to $250 \mathrm{~kg}$ of $\mathrm{N} / \mathrm{ha}$ originating from animal manure, rather than the default $170 \mathrm{~kg}$ of $\mathrm{N} / \mathrm{ha}$, if farms have at least 70 or $80 \%$ grassland (depending on country or region). In addition, for the more-intensive farms that can reduce their grassland area, it takes 44 years at the chain level before annual emission reduction has paid off emissions from land-use change (Van Mid- delaar et al., 2013). Most whole-farm models for life cycle assessment use empirical models to estimate $\mathrm{CH}_{4}$ emission, such as the IPCC Tier 2 model (IPCC, 2006) with a fixed $\mathrm{CH}_{4}$ conversion rate factor estimate $\mathrm{CH}_{4}$ output of dairy cows. Van Middelaar et al. (2013) used a mechanistic approach (Dijkstra et al., 1992; Bannink et al., 2006) and reported a $\mathrm{CH}_{4}$ reduction of $3.2 \%$ when increasing corn silage by $1 \mathrm{~kg}$ of $\mathrm{DM} /$ cow per day at the expense of grass and grass silage. When using the IPCC Tier 2 model to investigate the same dietary strategy, a $\mathrm{CH}_{4}$ reduction of $0.3 \%$ was achieved (C. van Middelaar, Animal Production Systems Group, Wageningen University \& Research, Wageningen, the Netherlands, unpublished data). This shows the importance of combining feed intake with diet composition in predictive models for $\mathrm{CH}_{4}$.

A financial reward or penalty may be an incentive for livestock farmers to apply GHG reduction technologies or management interventions. To implement such financial measures, it is necessary to monitor emissions at the farm level (Wirsenius et al., 2010). Emissions of $\mathrm{CH}_{4}$ from the digestive tract of ruminants are correlated with feed intake but can differ considerably between individual animals, even when feed composition and other factors are similar. For instance, for cattle consuming the same feed, emissions can vary by a factor of up to 2 (Lassey, 2007). Therefore, to accurately monitor farm-level emissions, rumen $\mathrm{CH}_{4}$ from a representative sample of the animals would have to be measured regularly. This is currently not possible in most cases, which is one of the reasons why, for instance, agricultural emissions were not included in the now-abrogated carbon tax scheme in Australia. The development of easy-to-measure and accurate proxies for $\mathrm{CH}_{4}$ would provide workable estimates of ruminant $\mathrm{CH}_{4}$ emissions at the individual animal level and help establish credible financial incentives to reduce dairy cattle GHG emissions.

\section{Applications of Proxies for Methane to Dairy Cattle Breeding}

Breeding objectives can sometimes be broadly defined or be difficult to measure directly on the large scale and as routinely as a breeding program requires. Examples include disease resistance, animal robustness/resilience, and fertility/reproductive performance. In such circumstances, indirect but correlated traits, which are well defined, readily available, and easy to measure, can be used as breeding criteria to approximate the breeding objective.

Minimizing the environmental impact and maximizing the metabolic efficiency of animals are 2 broad breeding objectives of current relevance in dairy cattle 
breeding. Methane emissions have been shown to be related to both objectives, but their routine measurement is difficult and expensive on an individual animal basis and on a larger scale. Instead, proxies for $\mathrm{CH}_{4}$ can be a valuable asset as indirect traits to be used in breeding for lower environmental impact or increased cow metabolic efficiency. Many of the proxies described in this review would provide breeders with excellent material (i.e., many standardized and repeatable phenotypic records) to work on selection of animals for novel traits or objectives. An indirect way to reduce $\mathrm{CH}_{4}$ emissions is to improve the productivity and efficiency of the dairy herd by selective breeding; for example, for milk yield, longevity, or calving interval (Bell et al., 2011). Improvements of a trait, such as milk yield or longevity, however, can affect whole-farm management, including feeding strategy and purchases of inputs, such as concentrate and fertilizer. Evaluating the effect of a genetic improvement, therefore, requires modeling the whole farm. Van Middelaar et al. (2014b) showed that in the current situation of maximizing income, the relative value of genetic traits to reduce GHG emissions along the dairy chain (the GHG value) of milk yield is higher than that of longevity. Thus, current efforts and objectives in breeding may already reduce GHG emissions per unit of milk. When the objective is to minimize GHG emissions (rather than to maximize income), the full potential of these traits is about doubled, indicating the greater progress that can be made by direct selection for reduced GHG emissions (Van Middelaar et al., 2014b).

Building an Index for Methane. Sometimes a single indicator trait is used as an indirect criterion for the breeding objective. This is the case for SCC, which is used to reflect indirectly the health status of the udder and, with a bigger jump, to loosely approximate mastitis. More often, though, multiple indirect traits are used to obtain a good approximation of the breeding objective. These multiple sources of information can be combined into an index for the breeding objective using selection index theory (e.g., Simm, 1998). An illustration is provided by cow fertility: cow fertility is a complex breeding objective that can be expressed, for instance, as conception rate. Measuring conception rate on a large scale and continuous basis is, however, expensive; instead, correlated indirect traits such as calving interval, angularity, and milk yield can be used to construct a selection index for fertility (e.g., Biffani et al., 2005).

Methane emissions provide another example of a phenotype that is difficult to measure individually on a large scale, and for which proxies can be assembled into an indirect index for $\mathrm{CH}_{4}$. The goal of selection index theory is to estimate the genetic component of the breeding objective (i.e., its breeding value) by assembling indirect traits into a weighted linear combination. Besides large-scale reliable records on the proxies, important building blocks of an indirect index are their heritabilities and the phenotypic and genetic correlations among proxies and between the proxies and the breeding objective (in this case, methane production/ intensity/yield). These are used to compute weights by maximizing the expected correlation between proxies and $\mathrm{CH}_{4}$. For some of the proxies, heritability and correlations with $\mathrm{CH}_{4}$ output are known; for example, Vanrobays et al. (2016) estimated heritability of 0.25 for $\mathrm{CH}_{4}$ production $(\mathrm{g} / \mathrm{d})$ and in the range from 0.17 to 0.42 for different classes of milk FA; phenotypic and genetic correlations between $\mathrm{MeP}$ and milk FA varied between -0.03 and 0.16 , and between -0.02 and 0.32 (C18:0), respectively. For most proxies, though, this information is still lacking or very preliminary. However, unknown correlations between variables may be derived from existing ones (Olkin, 1981); knowing the correlation between $\mathrm{X}$ and $\mathrm{Y}\left(r_{x y}\right)$, and that between $\mathrm{X}$ and $\mathrm{Z}$ $\left(r_{x z}\right)$, the acceptable range of the correlation between $\mathrm{Y}$ and $\mathrm{Z}\left(r_{y z}\right)$ falls within the following inequality:

$r_{x y} \times r_{x z}-\sqrt{\left(1-r_{x y}^{2}\right)\left(1-r_{x z}^{2}\right)} \leq r_{y z} \leq r_{x y} \times r_{x z}+\sqrt{\left(1-r_{x y}^{2}\right)\left(1-r_{x z}^{2}\right)}$.

For instance, the genetic correlation between MeI and milk yield estimated by Dehareng et al. (2012) was -0.45 , and the correlation between milk yield and protein percentage was -0.54 (Miglior et al., 2007). This would give a genetic correlation between MeI and protein percentage in the range $[-0.5,0.9]$, with likelier values for positive correlations. The most probable value in the given range could then be estimated (from the prior distribution of the missing correlation and the joint likelihood of the 2 known correlations given the values in the range).

Scaling $\boldsymbol{U p}$. The technological revolution in livestock farming is generating large amounts of data (Rutten et al., 2013; John et al., 2016). This also applies to some of the proxies described in this review, such as the continuous flow of data from automated milk recording systems (AMS) or from rumen sensors or pedometers. Advanced laboratory equipment, too, such as mid- or near-infrared analyzers, contribute to the amount of data. Such enormous data sets pose challenges for storage, processing, and analysis, thereby requiring a scaling-up of the data analysis systems used in breeding programs [e.g., using frameworks such as Apache Spark (Apache Spark, 2016) and TensorFlow (TensorFlow, 2016]. Not all proxies, however, are amenable to measurement on a large scale and on a routine basis (see Table 1). An important question to ask, therefore, is 
whether the relevant proxies should be measured only once in a lifetime on the whole population or multiple times on a large part of - but not all - the population. This would guide the choice of proxies to be used for the construction of the $\mathrm{CH}_{4}$ index. Additionally, genomic selection opens up the possibility of measuring phenotypes only in the nucleus or reference population, allowing for in-depth and continuous phenotyping without the practical limitations of collecting phenotypes on the larger commercial population.

Understanding Strengths, Limitations, and Potential Risks of Selecting for Methane. Methane emission is an emerging trait that could be included in a breeding objective to breed for cows that keep producing milk but do so in an efficient (reduced feed intake) and environmentally friendly manner. If we regard efficiency and environmental impact to be the goal, this is clearly a broad goal that cannot be easily measured on individual cows. Methane emissions, feed intake, and milk yield can thus be viewed as breeding criteria related to environmental impact (the first criterion) and production efficiency (the latter two). Additionally, the 3 criteria are mutually correlated. The associations among these breeding criteria and with the breeding goal are all relevant for the construction of the selection index for the improvement of the breeding goal, in a way similar to the index for $\mathrm{CH}_{4}$ described earlier. However, the relationships with the breeding goal ("environmental impact and production efficiency") and the weights of the breeding criteria are estimated through economic models or by simulating scenarios of genetic progress.

When including traits in the overall selection index or breeding program for a breed, it is important to be aware of potential unexpected consequences. For example: are there traits for which we do not want to select (against or in favor) but that are correlated with the breeding goals and would therefore be passively dragged by selection? A known illustration in dairy breeding is the somewhat inverse relation between milk yield, on one hand, and milk quality (e.g., fat and protein content) and animal functionality (e.g., fertility) on the other. A careful construction of the overall selection index and its implementation in the breeding program is therefore needed.

\section{A Final Note on Combinations of Proxies}

Combining proxies is a very powerful tool that can lead to highly accurate predictions of $\mathrm{CH}_{4}$ in dairy cattle. However, it is important to emphasize that predicting the $\mathrm{CH}_{4}$ phenotype and predicting the genetic or breeding value for $\mathrm{CH}_{4}$ output are different things.
The phenotype can be predicted with any appropriate statistical or machine learning method, possibly with very high accuracy. This can be useful for management purposes. However, the proxies combined in the predictive model may have different genetic background and variance, which would make it impossible to use the predicted $\mathrm{CH}_{4}$ phenotype directly in the estimation of (genomic)EBV. Under such circumstances, the use of a selection index approach would be preferable.

\section{PROXIES: FUTURE DEVELOPMENTS AND PERSPECTIVES}

In the last few years, efforts have been made to develop direct, reliable, and low-cost measures of $\mathrm{CH}_{4}$ emissions on an individual-animal basis. However, progress has not been as fast as desired, mainly because direct measurement of $\mathrm{CH}_{4}$ on an individual-animal basis is still difficult and expensive. This has stimulated the interest to look for proxies of $\mathrm{CH}_{4}$ output in dairy cattle.

Apart from management and nutrition, animal breeding could play a significant role in reducing the carbon footprint of dairy production systems (Hristov et al., 2013a; Knapp et al., 2014; Pickering et al., 2015). It is now possible to use genomic information to estimate genomic EBV for $\mathrm{CH}_{4}$ in the context of modern breeding schemes (Meuwissen et al., 2013; Hayes et al., 2013). However, this is only possible if large throughputs of $\mathrm{CH}_{4}$-related phenotypes are available. Calus et al. (2013) indicated that for genomic EBV to be implemented, a reference population of several thousand genotyped animals with $\mathrm{CH}_{4}$ phenotype measurements is needed to provide the initial estimates of the contribution of each genomic region to the expression of the phenotype under investigation. Genomic selection is the latest technology that opens the possibility of efficiently breeding for hard-to-measure and expensive traits, and $\mathrm{CH}_{4}$ from cattle belongs in this category. Success in this respect will ultimately depend, at least partly, on our ability to develop and identify proxies that are highly correlated with $\mathrm{CH}_{4}$, are relatively inexpensive, are not challenging logistically, and that can be measured on individual animals on a large scale.

There is currently limited consensus on which phenotype to use to lower the carbon footprint of milk production through genetic selection. This could be $\mathrm{MeP}, \mathrm{MeI}$, or MeY. The direct goal would be $\mathrm{CH}_{4}$ production; the relationship with milk production or feed intake could be accounted for by including these in the final selection index or scheme. However, it might be more effective or accurate to directly use milk production-corrected or feed intake-corrected $\mathrm{CH}_{4}$ (e.g., $\mathrm{CH}_{4}$ intensity or yield) as the breeding goal. Choosing the 
breeding goal is important in determining which combination of information sources (traits, relatives) should be used to build a selection index for $\mathrm{CH}_{4}$. Traits in the breeding goal and in the selection index can potentially be different: the breeding goal traits are those we want to influence genetically (i.e., carbon footprint of milk production), whereas the selection index traits are those we are actually measuring (i.e., proxies).

The analysis of proxies in terms of their attributes (Table 1) shows that proxies based on samples from the rumen or related to rumen sources are poor to moderately accurate predictors of $\mathrm{CH}_{4}$. In addition, these proxies are too costly and difficult for routine on-farm implementation. On the other hand, proxies related to BW, milk yield, and composition (e.g., milk FA) are moderately to highly accurate predictors of $\mathrm{CH}_{4}$ and are relatively simple, inexpensive, and easier to implement in practice. In particular, milk MIR and the prediction of $\mathrm{CH}_{4}$ based on milk MIR along with other covariates such as lactation stage is a promising alternative; that is; more accurate, cheaper, and more easily implemented in routine milk analysis at no extra cost. Based on proven chemometric methods that have been extensively used to develop quantitative predictive models for many novel traits (Gengler et al., 2016), extending current milk MIR-based predictions beyond the addition of lactation stage (Vanlierde, et al., 2015) toward the use of milk yield, maintenance-related traits such as BW, estimated or measured DMI, and other novel traits is relatively straightforward. As long as these sources of information are available together with MIR data, they can be easily integrated. Therefore, in the future, advances in infrared, photoacoustic, and related technologies will push the boundaries, particularly in focusing on developments of fast and portable technologies. Such developments will lead to better proxies for $\mathrm{CH}_{4}$ that will enable a sizable throughput of $\mathrm{CH}_{4}$ phenotypes in dairy cows.

In the future, more emphasis should be directed into developments in genomics and omics tools and particularly the way that these tools can be used to develop proxies for $\mathrm{CH}_{4}$ that have potential to increase the throughput of $\mathrm{CH}_{4}$ phenotypes. This is a requisite for accurate estimation of EBV and for developing sound animal breeding and selection strategies. The nextgeneration technology - omics - may become a future application for the detection of proxies present in various ruminant body fluids. Efforts should therefore be made to explore the possibilities wherein developments in the fields of proteomics and metabolomics could play a role in accurate prediction of $\mathrm{CH}_{4}$ and development of rapid assays for $\mathrm{CH}_{4}$ output. Antunes-Fernandes et al. (2016) already presented the use of metabolomics on milk to better understand the biological pathways involved in $\mathrm{CH}_{4}$ production in dairy cattle. The techniques used in that study are not suitable for large-scale measurements, but rapid developments in omics may offer tests and assay methodologies on blood, urine, or milk samples that will provide an additional tool for developing proxies for $\mathrm{CH}_{4}$ emissions in dairy cattle.

Proxies for $\mathrm{CH}_{4}$ have great implications in dairy management and breeding. In all of these applications, they can be used individually or in combination. However, there is no single perfect proxy for $\mathrm{CH}_{4}$ and we believe, therefore, that combining proxies is the best way forward. Combining proxies for $\mathrm{CH}_{4}$ will increase available information, statistical power, and hence accuracy of prediction. Furthermore, combining proxies will allow the description of independent sources of variations in $\mathrm{CH}_{4}$ emissions and result in the most accurate prediction of $\mathrm{CH}_{4}$ emissions in dairy cows. Substantial emphasis should therefore be directed toward proxies that are highly correlated with $\mathrm{CH}_{4}$ output but are inexpensive and noninvasive and could be easily measured on a large scale (e.g., milk MIR). It is important to underscore the fact that high phenotypic correlations are required to use proxies for management, whereas high genetic correlations are needed for their use in breeding. Finally, attention should be directed not only to the accuracy of proxies but also to their robustness. The reliable applicability of proxies under diverse environmental conditions, production systems, breeds, feeding systems, and so on is very important. So far, several different models and proxies have been developed for the prediction of $\mathrm{CH}_{4}$ output in ruminants. However, most such predictors and proxies tend to be accurate only for the production system and the environmental conditions under which they were developed. As a result, the greatest shortcoming today is the lack of robustness in their general applicability. International collaborations such as that initiated by the COST METHAGENE project (Methagene, 2013) are therefore essential. The next step in this area should focus on summarizing data from different environments, breeds, and production systems to come up with proxies that are not only accurate but also robust and applicable to diverse production systems and environments.

\section{ACKNOWLEDGMENTS}

This paper is the result of the concerted effort of all participants and support from the networks of COST Action FA1302 "Large-scale methane measurements on individual ruminants for genetic evaluations." The authors are grateful for all individuals and groups who have directly or indirectly contributed to this work, and 
particular thanks are due to the technical and financial support from the COST Action FA1302 of the European Union.

\section{REFERENCES}

Agnew, R. E., and T. Yan. 2000. The impact of recent research on energy feeding systems for dairy cattle. Livest. Prod. Sci. 66:197-215.

Agricultural Research Council. 1980. The Nutrient Requirements of Ruminant Livestock, Technical Review. CAB, Farnham Royal, UK.

Aguinaga Casañas, M. A., N. Rangkasenee, N. Krattenmacher, G. Thaller, C. C. Metges, and B. Kuhla. 2015. Methyl-coenzyme M reductase $\mathrm{A}$ as an indicator to estimate methane production from dairy cows. J. Dairy Sci. 98:4074-4083.

Alemu, A. W., J. Dijkstra, A. Bannink, J. France, and E. Kebreab. 2011. Rumen stoichiometric models and their contribution and challenges in predicting enteric methane production. Anim. Feed Sci. Technol. 166-167:761-778.

Ann, S. J., V. Kessel, and J. B. Russell. 1996. The effect of pH on ruminal methanogenesis. FEMS Microbiol. Ecol. 20:205-210.

Antunes-Fernandes, E. C., S. van Gastelen, J. Dijkstra, K. A. Hettinga, and J. Vervoort. 2016. Milk metabolome relates enteric methane emission to milk synthesis and energy metabolism pathways. J. Dairy Sci. 99:6251-6262.

Apache Spark. 2016. Lightning-fast cluster computing. Accessed Nov. 17, 2016. http://spark.apache.org/.

Arndt, C., J. M. Powell, M. J. Aguerre, P. M. Crump, and M. A. Wattiaux. 2015. Feed conversion efficiency in dairy cows: Repeatability, variation in digestion and metabolism of energy and nitrogen, and ruminal methanogens. J. Dairy Sci. 98:3938-3950.

Bannink, A., J. Kogut, J. Dijkstra, J. France, E. Kebreab, A. M. van Vuuren, and S. Tamminga. 2006. Estimation of the stoichiometry of volatile fatty acid production in the rumen of lactating cows. J. Theor. Biol. 238:36-51.

Bannink, A., M. W. van Schijndel, and J. Dijkstra. 2011. A model of enteric fermentation in dairy cows to estimate methane emission for the Dutch National Inventory Report using the IPCC Tier 3 approach. Anim. Feed Sci. Technol. 166-167:603-618.

Barnett, M. C., J. P. Goopy, J. R. McFarlane, I. R. Godwin, J. V. Nolan, and R. S. Hegarty. 2012. Triiodothyronine influences digesta kinetics and methane yield in sheep. Anim. Prod. Sci. 52:572-577.

Baskaran, R., R. Cullen, and S. Colombo. 2009. Estimating values of environmental impacts of dairy farming in New Zealand, New Zealand. J. Agric. Res. 52:377-389. https://doi. org/10.1080/00288230909510520.

Beauchemin, K. A., M. Kreuzer, F. O'Mara, and T. A. McAllister. 2008. Nutritional management for enteric methane abatement: A review. Aust. J. Exp. Agric. 48:21-27.

Beauchemin, K. A., T. A. McAllister, and S. M. McGinn. 2009. Dietary mitigation of enteric methane from cattle. CAB Rev. Perspect. Agric. Vet. Sci. Nutr. Nat. Res. 4:1-18.

Bell, M. J., E. Wall, G. Russell, G. Simm, and A. W. Stott. 2011. The effect of improving cow productivity, fertility, and longevity on the global warming potential of dairy systems. J. Dairy Sci. 94:3662-3678.

Berry, D. P., J. Lassen, and Y. de Haas. 2015. Residual feed intake and breeding approaches for enteric methane mitigation. Pages 273-291 in Livestock Production and Climate Change. P. K. Malik, R. Bhatta, J. Takahashi, R. A. Kohn, and C. S. Prasad, ed. CABI, Wallingford, UK.

Biffani, S., M. Marusi, F. Biscarini, and F. Canavesi. 2005. Developing a genetic evaluation for fertility using angularity and milk yield as correlated traits. Interbull Bull. 33:63.

Blaxter, K. L., and J. L. Clapperton. 1965. Prediction of the amount of methane produced by ruminants. Br. J. Nutr. 19:511-522.

Bouchard, K., K. M. Wittenberg, G. Legesse, D. O. Krause, E. Khafipour, K. E. Buckley, and K. H. Ominski. 2015. Comparison of feed intake, body weight gain, enteric methane emission and rela- tive abundance of rumen microbes in steers fed sainfoin and lucerne silages under western Canadian conditions. Grass Forage Sci. 70:116-129.

Brask, M., M. R. Weisbjerg, A. L. F. Hellwing, A. Bannink, and P. Lund. 2015. Methane production and diurnal variation measured in dairy cows and predicted from fermentation pattern and nutrient or carbon flow. Animal 9:1795-1806. https://doi.org/10.1017/ S1751731115001184.

Calus, M. P. L., Y. De Haas, M. Pszczola, and R. F. Veerkamp. 2013. Predicted accuracy of and response to genomic selection for new traits in dairy cattle. Animal 7:183-191.

Capper, J. L., R. A. Cady, and D. E. Bauman. 2009. The environmental impact of dairy production: 1944 compared with 2007. J. Anim. Sci. 87:2160-2167.

Castro Montoya, J., A. M. Bhagwat, N. Peiren, S. De Campeneere, B. De Baets, and V. Fievez. 2011. Relationships between odd- and branched-chain fatty acid profiles in milk and calculated enteric methane proportion for lactating dairy cattle. Anim. Feed Sci. Technol. 166:596-602.

Chilliard, Y., A. Ferlay, R. M. Mansbridge, and M. Doreau. 2000. Ruminant milk fat plasticity: Nutritional control of saturated, polyunsaturated, trans and conjugated fatty acids. Ann. Zootech. 49:181-205.

Chilliard, Y., C. Martin, J. Rouel, and M. Doreau. 2009. Milk fatty acids in dairy cows fed whole crude linseed, extruded linseed, or linseed oil, and their relationship with methane output. J. Dairy Sci. 92:5199-5211.

Chung, Y.-H., N. D. Walker, S. M. McGinn, and K. A. Beauchemin. 2011. Differing effects of 2 active dried yeast (Saccharomyces cerevisiae) strains on ruminal acidosis and methane production in non lactating dairy cows. J. Dairy Sci. 94:2431-2439.

Coffey, M. P., G. Simm, W. G. Hill, and S. Brotherstone. 2003. Genetic evaluations of dairy bulls for daughter energy balance profiles using linear type scores and body condition score analyzed using random regression. J. Dairy Sci. 86:2205-2212.

Couvreur, S., C. Hurtaud, P. G. Marnet, P. Faverdin, and J. L. Peyraud. 2007. Composition of milk fat from cows selected for milk fat globule size and offered either fresh pasture or a corn silage-based diet. J. Dairy Sci. 90:392-403

de Haas, Y., J. J. Windig, M. P. L. Calus, J. Dijkstra, M. de Haan, A. Bannink, and R. F. Veerkamp. 2011. Genetic parameters for predicted methane production and potential for reducing enteric emissions through genomic selection. J. Dairy Sci. 94:6122-6134.

De Marchi, M., V. Toffanin, M. Cassandro, and M. Penasa. 2014. Invited review: Mid-infrared spectroscopy as phenotyping tool for milk traits. J. Dairy Sci. 97:1171-1186. https://doi.org/10.3168/ jds.2013-6799.

Dehareng, F., C. Delfosse, E. Froidmont, H. Soyeurt, C. Martin, N. Gengler, A. Vanlierde, and P. Dardenne. 2012. Potential use of milk mid-infrared spectra to predict individual methane emission of dairy cows. Animal 6:1694-1701.

Delfosse, C., E. Froidmont, J. A. Fernandez Pierna, C. Martin, and F. Dehareng. 2010. Estimation of methane emissions by dairy cows on the basis of milk composition. Proc. Greenhouse Gases and Animal Agriculture (GGAA) Conference, Banff, Canada. E. J. McGeough and S. M. McGinn, ed.

Demeyer, D. I., and C. J. van Nevel. 1975. Methanogenesis, an integrated part of carbohydrate fermentation and its control. Pages 366-382 in Digestion and Metabolism in the Ruminant. I. W. McDonald and A. C. I. Warner, ed. University of New England, Armidale, Australia.

Demment, M. W., and P. J. Van Soest. 1985. A nutritional explanation for body-size patterns of ruminant and nonruminant herbivores. Am. Nat. 125:641-672.

Denman, S. E., N. W. Tomkins, and C. S. McSweeney. 2007. Quantitation and diversity analysis of ruminal methanogenic populations in response to the antimethanogenic compound bromochloromethane. FEMS Microbiol. Ecol. 62:313-322.

Dijkstra, J., H. D. S. C. Neal, D. E. Beever, and J. France. 1992. Simulation of nutrient digestion, absorption and outflow in the rumen: model description. J. Nutr. 122:2239-2256. 
Dijkstra, J., S. van Gastelen, E. C. Antunes-Fernandes, D. Warner, B. Hatew, G. Klop, S. C. Podesta, H. J. van Lingen, K. A. Hettinga, and A. Bannink. 2016. Relationships between milk fatty acid profiles and enteric methane production in dairy cattle fed grass- or grass silage-based diets. Anim. Prod. Sci. 56:541-548.

Dijkstra, J., S. M. van Zijderveld, J. A. Apajalahti, A. Bannink, W. J. J. Gerrits, J. R. Newbold, H. B. Perdok, and H. Berends. 2011. Relationships between methane production and milk fatty acid profiles in dairy cattle. Anim. Feed Sci. Technol. 166-167:590-595.

Donoghue, K. A., R. M. Herd, S. H. Bird, P. F. Arthur, and R. F. Hegarty. 2013. Preliminary genetic parameters for methane production in Australian beef cattle. Pages 290-293 in Proc. Assoc. Advmt. Anim. Breed. Genet., Napier, New Zealand. AAABG, Massey University, Palmerston North, New Zealand.

Ellis, J. L., A. Bannink, J. France, E. Kebreab, and J. Dijkstra. 2010. Evaluation of enteric methane prediction equations for dairy cows used in whole farm models. Glob. Change Biol. 16:3246-3256.

Ellis, J. L., E. Kebreab, N. E. Odongo, B. W. McBride, E. K. Okine, and J. France. 2007. Prediction of methane production from dairy and beef cattle. J. Dairy Sci. 90:3456-3466.

Fievez, V., E. Colman, J. M. Castro-Montoya, I. Stefanov, and B. Vlaeminck. 2012. Milk odd- and branched-chain fatty acids as biomarkers of rumen function-An update. Anim. Feed Sci. Technol. 172:51-65.

Fitzsimons, C., D. A. Kenny, M. H. Deighton, A. G. Fahey, and M. McGee. 2013. Methane emissions, body composition, and rumen fermentation traits of beef heifers differing in residual feed intake. J. Anim. Sci. 91:5789-5800.

Freetly, H. C., and T. M. Brown-Brandl. 2013. Enteric methane production from beef cattle that vary in feed efficiency. J. Anim. Sci. 91:4826-4831.

Froidmont, C., F. Delfosse, F. Dehareng, C. Martin, V. Decruyneaere, N. Bartiaux-Thill, and P. Dardenne. 2010. Estimation of methane emission by dairy cows according to NIRS prediction of feces composition. Proc. Greenhouse Gases and Animal Agriculture (GGAA) Conference, Banff, Canada. E. J. McGeough and S. M. McGinn, ed.

Garnsworthy, P. C., J. Craigon, J. H. Hernandez-Medrano, and N. Saunders. 2012. Variation among individual dairy cows in methane measurements made on farm during milking. J. Dairy Sci. 95:3181-3189.

Gengler, N., H. Soyeurt, F. Dehareng, C. Bastin, F. Colinet, H. Hammami, M.-L. Vanrobays, A. Lainé, S. Vanderick, C. Grelet, A Vanlierde, E. Froidmont, and P. Dardenne. 2016. Capitalizing on fine milk composition for breeding and management of dairy cows. J. Dairy Sci. 99:4071-4079.

Gerber, P. J., and H. Steinfeld. 2008. Worldwide growth of animal production and environmental consequences. Pages 21-32 in Trace Elements in Animal Production Systems. P. S. Schlegel, P. S. Durosoy and A. W. Jongbloed, ed. Wageningen Academic Publishers, Wageningen, the Netherlands.

Gerber, P. J., H. Steinfeld, B. Henderson, A. Mottet, C. Opio, J. Dijkman, A. Falcucci, and G. Tempio. 2013. Tackling climate change through livestock-A global assessment of emissions and mitigation opportunities. Food and Agriculture Organization of the United Nations (FAO), Rome, Italy.

Gill, F. L., R. J. Dewhurst, J. A. J. Dungait, R. P. Evershed, L. Ives, C. S. Li, R. D. Pancost, M. Sullivan, S. Bera, and I. D. Bull. 2010. Archaeol-A biomarker for foregut fermentation in modern and ancient herbivorous mammals? Org. Geochem. 41:467-472.

Goopy, J. P., A. Donaldson, R. Hegarty, P. E. Vercoe, F. Haynes, M. Barnett, and V. H. Oddy. 2014. Low-methane yield sheep have smaller rumens and shorter rumen retention time. Br. J. Nutr. 111:578-585

Grainger, C., and K. A. Beauchemin. 2011. Can enteric methane emissions from ruminants be lowered without lowering their production? Anim. Feed Sci. Technol. 166-167:308-320.

Guyader, J., M. Eugène, P. Nozière, D. P. Morgavi, M. Doreau, and C. Martin. 2014. Influence of rumen protozoa on methane emission in ruminants: A meta-analysis approach. Animal 8:1816-1825.
Haisan, J., Y. Sun, L. L. Guan, K. A. Beauchemin, A. Iwaasa, S. Duval, D. R. Barreda, and M. Oba. 2014. The effects of feeding 3-nitrooxypropanol on methane emissions and productivity of Holstein cows in mid lactation. J. Dairy Sci. 97:3110-3119.

Hammond, K. J., J. L. Burke, J. P. Koolaard, S. Muetzel, C. S. Pinares-Patiño, and G. C. Waghorn. 2013. Effects of feed intake on enteric methane emissions from sheep fed fresh white clover ( Trifolium repens) and perennial ryegrass (Lolium perenne) forages. Anim. Feed Sci. Technol. 197:121-132.

Hammond, K. J., L. A. Crompton, A. Bannink, J. Dijkstra, D. R. Yáñez-Ruiz, P. O'Kiely, E. Kebreab, M. A. Eugène, Z. Yu, K. J. Shingfield, A. Schwarm, A. N. Hristov, and C. K. Reynolds. 2016. Review of current in vivo measurement techniques for quantifying enteric methane emission from ruminants. Anim. Feed Sci. Technol. 219:13-30.

Harb, M. Y., and R. C. Campling. 1985. Variation among pregnant, non-lactating dairy cows in eating and ruminating behaviour, digestibility and voluntary intake of hay. Grass Forage Sci. 40:109111.

Hayes, B. J., H. A. Lewin, and M. E. Goddard. 2013. The future of livestock breeding: genomic selection for efficiency, reduced emissions intensity, and adaptation. Trends Genet. 29:206-214.

Hegarty, R. S. 1999. Reducing rumen methane emissions through elimination of rumen protozoa. Aust. J. Agric. Res. 50:1321-1327.

Hegarty, R. S., J. P. Goopy, R. M. Herd, and B. McCorkell. 2007. Cattle selected for lower residual feed intake have reduced daily methane production. J. Anim. Sci. 85:1479-1486.

Henderson, G., F. Cox, S. Ganesh, A. Jonker, W. YoungGlobal Rumen Census Collaborators, and P. H. Janssen. 2015. Rumen microbial community composition varies with diet and host, but a core microbiome is found across a wide geographical range. Sci. Rep. 5:14567 https://doi.org/10.1038/srep14567.

Herd, R. M., P. F. Arthur, S. H. Bird, K. A. Donoghue, and R. S. Hegarty. 2014. Genetic variation for methane traits in beef cattle. Proc. 10th World Conference on Genetics Applied to Livestock Production (WCGALP), Vancouver, Canada. Am. Soc. Anim. Sci., Champaign, IL.

Herd, R. M., S. H. Bird, K. A. Donoghue, P. F. Arthur, and R. S. Hegarty. 2013. Phenotypic associations between methane production traits, volatile fatty acids and animal breeding traits. Pages 286-289 in Proc. Assoc. Advmt. Anim. Breed. Genet., Napier, New Zealand. AAABG, Massey University, Palmerston North, New Zealand.

Holter, J. B., and A. J. Young. 1992. Methane production in dry and lactating Holstein cows. J. Dairy Sci. 75:2165-2175.

Hristov, A. N., K. A. Johnson, and E. Kebreab. 2014. Livestock methane emissions in the United States. Proc. Natl. Acad. Sci. USA 111:E1320 https://doi.org/10.1073/pnas.1401046111.

Hristov, A. N., J. Oh, J. L. Firkins, J. Dijkstra, E. Kebreab, G. Waghorn, H. P. S. Makkar, A. T. Adesogan, W. Yang, C. Lee, P. J. Gerber, B. Henderson, and J. M. Tricarico. 2013b. Special topics - Mitigation of methane and nitrous oxide emissions from animal operations: I. A review of enteric methane mitigation options. J. Anim. Sci. 91:5045-5069.

Hristov, A. N., T. Ott, J. Tricarico, A. Rotz, G. Waghorn, A. Adesogan, J. Dijkstra, F. Montes, J. Oh, E. Kebreab, S. J. Oosting, P. J. Gerber, B. Henderson, H. P. S. Makkar, and J. L. Firkins. 2013a. Special topics - Mitigation of methane and nitrous oxide emissions from animal operations: III. A review of animal management mitigation options. J. Anim. Sci. 91:5095-5113.

IPCC. 2006. IPCC Guidelines for National Greenhouse Gas Inventories. Prepared by the National Greenhouse Gas Inventories Program. H. S. Eggleston, L. Buendia, K. Miwa, T. Ngara, and K. Tanabe, ed. IGES, Hayama, Japan.

Iwamoto, M., N. Asanuma, and T. Hino. 2002. Ability of Selenomonas ruminantium, Veillonella parvula, and Wolinella succinogenes to reduce nitrate and nitrite with special reference to the suppression of ruminal methanogenesis. Anaerobe 8:209-215.

John, A. J., C. E. Clark, M. J. Freeman, K. L. Kerrisk, S. C. Garcia, and I. Halachmi. 2016. Review: Milking robot utilization, a successful precision livestock farming evolution. Animal 10:1484-1492. 
Jones, F. M., F. A. Phillips, T. Naylor, and N. B. Mercer. 2011. Methane emissions from grazing Angus beef cows selected for divergent residual feed intake. Anim. Feed Sci. Technol. 166:302-307.

Jonker, A., G. Molano, C. Antwi, and G. Waghorn. 2014. Feeding lucerne silage to beef cattle at three allowances and four feeding frequencies affects circadian patterns of methane emissions, but not emissions per unit of intake. Anim. Prod. Sci. 54:1350-1353.

Kandel, P. B., S. Vanderick, M.-L. Vanrobays, A. Vanlierde, F. Dehareng, E. Froidmont, H. Soyeurt, and N. Gengler. 2014. Consequences of selection for environmental impact traits in dairy cows. Proc. 10th World Congress on Genetics Applied to Livestock Production (WCGALP), Vancouver, Canada. Am. Soc. Anim. Sci., Champaign, IL.

Kirchgessner, M., W. Windisch, and H. L. Muller. 1995. Nutritional factors for the quantification of methane production. In Ruminant Physiology: Digestion, Metabolism, Growth and Reproduction. Pages 333-348 in Proc. 8th Int. Symp. Ruminant Physiology. W. Von Engelhardt, S. Leonhard-Marek, G. Breves and D. Giesecke, ed. Ferdinand Enke Verlag, Stuttgart, Germany.

Kittelmann, S., C. S. Pinares-Patiño, H. Seedorf, M. R. Kirk, S. Ganesh, J. C. McEwan, and P. H. Janssen. 2014. Two different bacterial community types are linked with the low-methane emission trait in sheep. PLoS One 9:e103171.

Knapp, J. R., G. L. Laur, P. A. Vadas, W. P. Weiss, and J. M. Tricarico. 2014. Invited review: Enteric methane in dairy cattle production: Quantifying the opportunities and impact of reducing emissions. J. Dairy Sci. 97:3231-3261.

Knight, T., R. S. Ronimus, D. Dey, C. Tootill, G. Naylor, P. Evans, G. Molano, A. Smith, M. Tavendale, C. S. Pinares-Patiño, and H. Clark. 2011. Chloroform decreases rumen methanogenesis and methanogen populations without altering rumen function in cattle. Anim. Feed Sci. Technol. 166-167:101-112.

Kubo, I., H. Muroi, M. Himejima, Y. Yamagiwa, H. Mera, K. Tokushima, S. Ohta, and T. Kamikawa. 1993. Structure-antibacterial activity relationships of anacardic acids. J. Agric. Food Chem. 41:1016-1019.

Kuzuhara, Y., K. Kawamura, R. Yoshitoshi, T. Tamaki, S. Sugai, M. Ikegami, Y. Kurokawa, T. Obitsu, M. Okita, T. Sugino, and T. Yasuda. 2015. A preliminarily study for predicting body weight and milk properties in lactating Holstein cows using a three-dimensional camera system. Comput. Electron. Agric. 111:186-193.

Lassen, J., and P. Løvendahl. 2016. Heritability estimates for enteric methane emissions from Holstein cattle measured using noninvasive methods. J. Dairy Sci. 99:1959-1967.

Lassey, K. R. 2007. Livestock methane emission: From the individual grazing animal through national inventories to the global methane cycle. Agric. Meteorol. 142:120-132.

Martin, C., D. P. Morgavi, and M. Doreau. 2010. Methane mitigation in ruminants: From microbe to the farm scale. Animal 4:351-365.

Martin-Collado, D., T. Byrne, P. Amer, B. Santos, M. Axford, and J. Pryce. 2015. Analyzing the heterogeneity of farmers' preferences for improvements in dairy cow traits using farmer typologies. J. Dairy Sci. 98:4148-4161.

McCartney, C. A., I. D. Bull, and R. J. Dewhurst. 2014b. Using archaeol to investigate the location of methanogens in the ruminant digestive tract. Livest. Sci. 164:39-45.

McCartney, C. A., I. D. Bull, S. M. Waters, and R. J. Dewhurst. 2013a. Technical note: Comparison of biomarker and molecular biological methods for estimating methanogen abundance. J. Anim. Sci. 91:5724-5728.

McCartney, C. A., I. D. Bull, T. Yan, and R. J. Dewhurst. 2013b. Assessment of archaeol as a molecular proxy for methane production in cattle. J. Dairy Sci. 96:1211-1217.

McCartney, C. A., R. J. Dewhurst, and I. D. Bull. 2014a. Changes in the ratio of tetraether to diether lipids in cattle feces in response to altered dietary ratio of grass silage and concentrates. J. Anim. Sci. 92:4095-4098.

McDonnell, R. P., K. J. Hart, T. M. Boland, A. K. Kelly, M. McGee, and D. A. Kenny. 2016. Effect of divergence in phenotypic residual feed intake on methane emissions, ruminal fermentation, and apparent whole-tract digestibility of beef heifers across three contrasting diets. J. Anim. Sci. 94:1179-1193.

Methagene. 2013. METHAGENE EU COST Action FA1302 on largescale methane measurements on individual ruminants for genetic evaluations. Accessed Nov. 17, 2016. http://www.methagene.eu/.

Meuwissen, T., B. Hayes, and M. Goddard. 2013. Accelerating improvement of livestock with genomic selection. Annu. Rev. Anim. Biosci. 1:221-237.

Miglior, F., A. Sewalem, J. Jamrozik, J. Bohmanova, D. M. Lefebvre, and R. K. Moore. 2007. Genetic analysis of milk urea nitrogen and lactose and their relationships with other production traits in Canadian Holstein cattle. J. Dairy Sci. 90:2468-2479.

Mills, J. A. N., E. Kebreab, C. M. Yates, L. A. Crompton, S. B. Cammell, M. S. Dhanoa, R. E. Agnew, and J. France. 2003. Alternative approaches to predicting methane emissions from dairy cows. J. Anim. Sci. 81:3141-3150.

Mohammed, R., S. M. McGinn, and K. A. Beauchemin. 2011. Prediction of enteric methane output from milk fatty acid concentrations and rumen fermentation parameters in dairy cows fed sunflower, flax, or canola seeds. J. Dairy Sci. 94:6057-6068.

Moorby, J. M., H. R. Fleming, V. J. Theobald, and M. D. Fraser. 2015. Can live weight be used as a proxy for enteric methane emissions from pasture-fed sheep? Sci. Rep. 5:17915.

Moraes, L. E., A. B. Strathe, J. G. Fadel, D. P. Casper, and E. Kebreab. 2014. Prediction of enteric methane emissions from cattle. Glob. Chang. Biol. 20:2140-2148.

Morgavi, D. P.. E. Forano, C. Martin, and C. J. Newbold. 2010. Microbial ecosystem and methanogenesis in ruminants. Animal 4:1024-1036

Morgavi, D. P., C. Martin, J. P. Jouany, and M. J. Ranilla. 2012 Rumen protozoa and methanogenesis: not a simple cause-effect relationship. Br. J. Nutr. 107:388-397. https://doi.org/10.1017/ S0007114511002935.

Moss, A. R., J. P. Jouany, and J. Newbold. 2000. Methane production by ruminants: Its contribution to global warming. Ann. Zootech. 49:231-253.

Muñoz, C., T. Yan, D. A. Wills, S. Murray, and A. W. Gordon. 2012. Comparison of the sulfur hexafluoride tracer and respiration chamber techniques for estimating methane emissions and correction for rectum methane output from dairy cows. J. Dairy Sci. 95:31393148 .

Murray, R. M., A. M. Bryant, and R. A. Leng. 1976. Rates of production of methane in the rumen and large intestine of sheep. Br. J. Nutr. 36:1-14

Negussie, E., J. Lehtinen, P. Mäntysaari, A.-E. Liinamo, E. Mäntysaari, and M. Lidauer. 2016. Non-invasive individual methane measurements in dairy cows using photoacoustic infrared spectroscopy technique. Page 62 in 6th Greenhouse Gases Animal Agriculture Conference (GGAA2016), Melbourne, Australia.

Negussie, E., P. Mäntysaari, E. A. Mäntysaari, and M. Lidauer. 2014. Animal wise variation in enteric methane output traits and its relationships with feed efficiency in dairy cattle: A longitudinal model analysis. Proc. 10th World Congress of Genetics Applied to Livestock Production, Vancouver, Canada. Am. Soc. Anim. Sci., Champaign, IL.

Newbold, C. J., G. de la Fuente, A. Belanche, E. Ramos-Morales, and N. McEwan. 2015. The role of ciliate protozoa in the rumen. Front. Microbiol. 6:1313 https://doi.org/10.3389/fmicb.2015.01313.

Nielsen, H. M., and P. R. Amer. 2007. An approach to derive economic weights in breeding objectives using partial profile choice experiments. Animal 1:1254-1262.

Nkrumah, J. D., E. K. Okine, G. W. Mathison, K. Schmid, C. Li, J. A. Basarab, M. A. Price, Z. Wang, and S. S. Moore. 2006. Relationships of feedlot feed efficiency, performance, and feeding behavior with metabolic rate, methane production, and energy partitioning in beef cattle. J. Anim. Sci. 84:145-153.

Okine, E. K., G. W. Mathison, and R. T. Hardin. 1989. Effects of changes in frequency of reticular contractions on fluid and particulate passage rates in cattle. J. Anim. Sci. 67:3388-3396.

Olkin, I. 1981. Range restrictions for product-moment correlation matrices. Psychometrika 46:469-472. 
Ørskov, E. R., and M. Ryle. 1990. Energy Nutrition in Ruminants. Elsevier Applied Science Publisher, London, UK.

Pickering, N. K., V. H. Oddy, J. A. Basarab, K. Cammack, B. J. Hayes, R. S. Hegarty, J. C. McEwan, S. Miller, C. Pinares, and Y. de Haas. 2015. Invited review: Genetic possibilities to reduce enteric methane emissions from ruminants. Animal 9:1431-1440.

Pinares-Patiño, C. S., S. M. Hickey, E. A. Young, K. G. Dodds, S. MacLean, G. Molano, E. Sandoval, H. Kjestrup, R. Harland, N. K. Pickering, and J. C. McEwan. 2013. Heritability estimates of methane emissions from sheep. Animal 7:316-321.

Pinares-Patiño, C. S., M. J. Ulyatt, K. R. Lassey, T. N. Barry, and C. W. Holmes. 2003. Rumen function and digestion parameters associated with differences between sheep in methane emissions when fed chaffed lucerne hay. J. Agric. Sci. 140:205-214.

Popova, M., C. Martin, M. Eugène, M. M. Mialon, M. Doreau, and D. P. Morgavi. 2011. Effect of fibre- and starch-rich finishing diets on methanogenic Archaea diversity and activity in the rumen of feedlot bulls. Anim. Feed Sci. Technol. 166-167:113-121.

Poulsen, M., S. Clarissa, J. Bent Borg, M. E. Ricarda, S. Anja, C. Nuria, H. Ole, M. Gabriel, F. Lena, S. Christa, W. Wolfram, L. Peter, S. Andreas, and U. Tim. 2013. Methylotrophic methanogenic Thermoplasmata implicated in reduced methane emissions from bovine rumen. Nat. Commun. 4:1428.

Ramin, M., and P. Huhtanen. 2013. Development of equations for predicting methane emissions from ruminants. J. Dairy Sci. 96:24762493.

Rico, D. E., P. Y. Chouinard, F. Hassanat, C. Benchaar, and R. Gervais. 2016. Prediction of enteric methane emissions from Holstein dairy cows fed various forage sources. Animal 10:203-211. https:// doi.org/10.1017/S1751731115001949.

Roehe, R., R. J. Dewhurst, C.-A. Duthie, J. A. Rooke, N. McKain, D. W. Ross, J. J. Hyslop, A. Waterhouse, T. C. Freeman, M. Watson, and R. J. Wallace. 2016. Bovine host genetic variation influences rumen microbial methane production with best selection criterion for low methane emitting and efficiently feed converting hosts based on metagenomic gene abundance. PLoS Genet. 12:e1005846. https://doi.org/10.1371/journal.pgen.1005846.

Romero-Perez, A., E. K. Okine, S. M. McGinn, L. L. Guan, M. Oba, S. M. Duval, M. Kindermann, and K. A. Beauchemin. 2014. The potential of 3-nitrooxypropanol to lower enteric methane emissions from beef cattle. J. Anim. Sci. 92:4682-4693.

Romero-Perez, A., E. K. Okine, S. M. McGinn, L. L. Guan, M. Oba, S. M. Duval, M. Kindermann, and K. A. Beauchemin. 2015. Sustained reduction in methane production from long-term addition of 3-nitrooxypropanol to a beef cattle diet. J. Anim. Sci. 93:17801791

Ross, E. M., P. J. Moate, L. C. Marett, B. G. Cocks, and B. J. Hayes. 2013a. Investigating the effect of two methane-mitigating diets on the rumen microbiome using massively parallel sequencing. J. Dairy Sci. 96:6030-6046.

Ross, E. M., P. J. Moate, L. C. Marett, B. G. Cocks, and B. J. Hayes. 2013b. Metagenomic predictions: From microbiome to complex health and environmental phenotypes in humans and cattle. PLoS One https://doi.org/10.1371/journal.pone.0073056.

Rutten, C. J., A. G. Velthuis, W. Steeneveld, and H. Hogeveen. 2013. Invited review: Sensors to support health management on dairy farms. J. Dairy Sci. 96:1928-1952.

Schirmann, K., N. Chapinal, D. M. Weary, W. Heuwieser, and M. A. G. von Keyserlingk. 2012. Rumination and its relationship to feeding and lying behavior in Holstein dairy cows. J. Dairy Sci. 95:3212-3217.

Schwarm, A., M. Schweigel-Röntgen, M. Kreuzer, S. Ortmann, F. Gill, B. Kuhla, U. Meyer, M. Lohölter, and M. Derno. 2015. Methane emission, digestive characteristics and faecal archaeol in heifers fed diets based on silage from brown midrib maize as compared to conventional maize. Arch. Anim. Nutr. 69:159-176.

Shi, W., C. D. Moon, S. C. Leahy, D. Kang, J. Froula, S. Kittelmann, C. Fan, S. Deutsch, D. Gagic, H. Seedorf, W. J. Kelly, R. Atua, C. Sang, P. Soni, D. Li, C. S. Pinares-Patiño, J. C. McEwan, P. H. Janssen, F. Chen, A. Visel, Z. Wang, G. T. Attwood, and E. M.
Rubin. 2014. Methane yield phenotypes linked to differential gene expression in the sheep rumen microbiome. Genome Res. https:// doi.org/10.1101/gr.168245.113.

Shinkai, T., O. Enishi, M. Mitsumori, K. Higuchi, Y. Kobayashi, A Takenaka, K. Nagashima, and M. Mochizuki. 2012. Mitigation of methane production from cattle by feeding cashew nut shell liquid. J. Dairy Sci. 95:5308-5316.

Simm, G. 1998. Genetic Improvement of Cattle and Sheep. Farming Press Books and Videos, Ipswich, UK.

Soyeurt, H., F. Dehareng, N. Gengler, S. McParland, E. Wall, D. P. Berry, M. Coffey, and P. Dardenne. 2011. Mid-infrared prediction of bovine milk fatty acids across multiple breeds, production systems and countries. J. Dairy Sci. 94:1657-1667.

Stergiadis, S., C. X. Zou, X. J. Chen, M. Allen, D. Wills, and T. Yan. 2016. Equations to predict methane emissions from cows fed at maintenance energy level in pasture-based systems. Agric. Ecosyst. Environ. 220:8-20.

Sun, X., G. Henderson, F. Cox, G. Molano, S. J. Harrison, D. Luo, P. H. Janssen, and D. Pacheco. 2015. Lambs fed fresh winter forage rape (Brassica napus L.) emit less methane than those fed perennial ryegrass (Lolium perenne L.), and possible mechanisms behind the difference. PLoS One 10:e0119697. https://doi.org/10.1371/ journal.pone.0119697.

TensorFlow. 2016. TensorFlow is an Open Source Software Library for Machine Intelligence. Accessed Nov. 17, 2016. https://www. tensorflow.org/.

van Gastelen, S., E. C. Antunes-Fernandes, K. A. Hettinga, G. Klop, S. J. J. Alferink, W. H. Hendriks, and J. Dijkstra. 2015. Enteric methane production, rumen volatile fatty acid concentrations, and milk fatty acid composition in lactating Holstein-Friesian cows fed grass silage- or corn-silage based diets. J. Dairy Sci. 98:1915-1927.

van Gastelen, S., and J. Dijkstra. 2016. Prediction of methane emission from lactating dairy cows using milk fatty acids and midinfrared spectroscopy. J. Sci. Food Agric. 96:3963-3968.

van Lingen, H. J., L. A. Crompton, W. H. Hendriks, C. K. Reynolds, and J. Dijkstra. 2014. Meta-analysis of relationships between enteric methane yield and milk fatty acid profile in dairy cattle. J. Dairy Sci. 97:7115-7132.

van Middelaar, C. E., P. B. M. Berentsen, J. Dijkstra, and I. J. M. De Boer. 2013. Evaluation of a feeding strategy to reduce greenhouse emissions from dairy farming: The level of analysis matters. Agric. Syst. 121:9-22.

van Middelaar, C. E., P. B. M. Berentsen, J. Dijkstra, J. A. M. Van Arendonk, and I. J. M. De Boer. 2014a. Methods to determine the relative value of genetic traits in dairy cows to reduce greenhouse gas emissions along the chain. J. Dairy Sci. 97:5191-5205.

van Middelaar, C. E., J. Dijkstra, P. B. M. Berentsen, and I. J. M. De Boer. 2014b. Cost-effectiveness of feeding strategies to reduce greenhouse gas emissions from dairy farming. J. Dairy Sci 97:2427-2439.

van Zijderveld, S. M., W. J. J. Gerrits, J. A. Apajalahti, J. R. Newbold, J. Dijkstra, R. A. Leng, and H. B. Perdok. 2010. Nitrate and sulfate: Effective alternative hydrogen sinks for mitigation of ruminal methane production in sheep. J. Dairy Sci. 93:5856-5866.

Vanlierde, A., F. Dehareng, E. Froidmont, P. Dardenne, P. B. Kandel, N. Gengler, M. H. Deighton, F. Buckley, E. Lewis, S. McParland, D. P. Berry, and H. Soyeurt. 2013. Prediction of the individual enteric methane emission of dairy cows from milk-mid-infrared spectra. Advances in Animal Biosciences. Pages 433 in Proc. 5th Greenhouse Gases Animal Agriculture Conference (GGAA2013), Dublin, Ireland. Cambridge Journals, Cambridge, UK.

Vanlierde, A., M. L. Vanrobays, F. Dehareng, E. Froidmont, H. Soyeurt, S. McParland, E. Lewis, M. H. Deighton, F. Grandl, M. Kreuzer, B. Grendler, P. Dardenne, and N. Gengler. 2015. Hot topic: Innovative lactation-stage-dependent prediction of methane emissions from milk mid-infrared spectra. J. Dairy Sci. 98:57405747 .

Vanlierde, A., M.-L. Vanrobays, N. Gengler, P. Dardenne, E. Froidmont, H. Soyeurt, S. McParland, E. Lewis, M. H. Deighton, M. Mathot, and F. Dehareng. 2016. Milk mid-infrared spectra enable 
prediction of lactation-stage-dependent methane emissions of dairy cattle within routine population-scale milk recording schemes. Anim. Prod. Sci. 56:258-264.

Vanrobays, M.-L., C. Bastin, J. Vandenplas, H. Hammami, H. Soyeurt, A. Vanlierde, F. Dehareng, E. Froidmont, and N. Gengler. 2016. Changes throughout lactation in phenotypic and genetic correlations between methane emissions and milk fatty acid contents predicted from milk mid-infrared spectra. J. Dairy Sci. 99:72477260. https://doi.org/10.3168/jds.2015-10646.

Veneman, J. B., S. Muetzel, K. J. Hart, C. L. Faulkner, J. M. Moorby, H. B. Perdok, and C. J. Newbold. 2015. Does dietary mitigation of enteric methane production affect rumen function and animal productivity in dairy cows? PLoS One 10:e0140282. https://doi. org/10.1371/journal.pone.0140282.

Vlaeminck, B., V. Fievez, A. R. J. Cabrita, A. J. M. Fonseca, and R. J. Dewhurst. 2006. Factors affecting odd- and branched-chain fatty acids in milk: A review. Anim. Feed Sci. Technol. 131:389-417.

Wall, E., G. Simm, and D. Moran. 2010. Developing breeding schemes to assist mitigation of greenhouse gas emissions. Animal 4:366-376.

Wallace, R. J., J. Rooke, N. McKain, C.-A. Duthie, J. Hyslop, D. Ross, A. Waterhouse, M. Watson, and R. Roehe. 2015. The rumen microbial metagenome associated with high methane production in cattle. BMC Genomics 16:839.

Wallace, R. J., J. A. Rooke, C.-A. Duthie, J. J. Hyslop, D. W. Ross, N. McKain, S. M. de Souza, T. J. Snelling, A. Waterhouse, and R. Roehe. 2014. Archaeal abundance in post-mortem ruminal digesta may help predict methane emissions from beef cattle. Sci. Rep. 4:5892.

Wang, C., Q. Liu, Y. L. Zhang, C. X. Pei, S. L. Zhang, Y. X. Wang, W. Z. Yang, Y. S. Bai, Z. G. Shi, and X. N. Liu. 2015. Effects of isobutyrate supplementation on ruminal microflora, rumen enzyme activities and methane emissions in Simmental steers. J. Anim. Physiol. Anim. Nutr. (Berl.) 99:123-131.

Warner, D., B. Hatew, S. C. Podesta, G. Klop, S. van Gastelen, H. van Laar, J. Dijkstra, and A. Bannink. 2016. Effects of nitrogen fertilisation rate and maturity of grass silage on methane emission by lactating dairy cows. Animal 10:34-43.

Watt, L. J., C. E. F. Clark, G. L. Krebs, C. E. Petzel, S. Nielsen, and S. A. Utsumi. 2015. Differential rumination, intake, and enteric methane production of dairy cows in a pasture-based automatic milking system. J. Dairy Sci. 98:7248-7263.
Williams, S. R. O., B. Williams, P. J. Moate, M. H. Deighton, M. C. Hannah, and W. J. Wales. 2014. Methane emissions of dairy cows cannot be predicted by the concentrations of C8:0 and total C18 fatty acids in milk. Anim. Prod. Sci. 54:1757-1761. https://doi. org/10.1071/AN14292.

Wirsenius, S., G. Berndes, and C. Azar. 2010. How much land is needed for global food production under scenarios of dietary changes and livestock productivity increases in 2030? Agric. Syst. 103:621636. https://doi.org/10.1016/j.agsy.2010.07.005.

Wuchter, C., S. Schouten, M. J. L. Coolen, and J. S. S. Damste. 2004. Temperature-dependent variation in the distribution of tetraether membrane lipids of marine Crenarchaeota: Implications for TEX86 paleothermometry. Paleoceanography 19:PA4028.

Yan, T. 2016. Comparison of enteric methane emissions of lactating dairy cows between Holstein-Friesian and Norwegian breeds. Page 129 in Proc. 6th Greenhouse Gases and Animal Agriculture, Melbourne, Australia.

Yan, T., R. E. Agnew, F. J. Gordon, and M. G. Porter. 2000. The prediction of methane energy output in dairy and beef cattle offered grass silage-based diets. Livest. Prod. Sci. 64:253-263.

Yan, T., C. S. Mayne, F. G. Gordon, M. G. Porter, R. E. Agnew, D. C. Patterson, C. P. Ferris, and D. J. Kilpatrick. 2010. Mitigation of enteric methane emissions through improving efficiency of energy utilization and productivity in lactating dairy cows. J. Dairy Sci. 93:2630-2638. https://doi.org/10.3168/jds.2009-2929.

Yan, T., C. S. Mayne, D. C. Patterson, and R. E. Agnew. 2009a. Prediction of body weight and empty body composition using body size measurements in lactating dairy cows. Livest. Sci. 124:233241

Yan, T., D. C. Patterson, C. S. Mayne, R. E. Agnew, and M. G. Porter. 2009b. Prediction of empty body weight and composition from live weight and other live animal measurements in lactating dairy cows. J. Agric. Sci. 147:241-251.

Yan, T., M. G. Porter, and S. C. Mayne. 2009c. Prediction of methane emission from beef cattle using data measured in indirect opencircuit respiration calorimeters. Animal 3:1455-1462.

Zhao, Y. G., N. E. O'Connell, and T. Yan. 2016. Prediction of enteric methane emissions from sheep offered fresh perennial ryegrass (Lolium perenne) using data measured in indirect open-circuit respiration chambers. J. Anim. Sci. 94:2425-2435. https://doi org/10.2527/jas.2016-0334. 